\title{
CRYSTALLIZATION HISTORY OF SOME POSTMETAMORPHIC DIABASES IN ÅLAND, HÄME AND SATAKUNTA, FINLAND. A THEORETICAL AND EXPERIMENTAL STUDY
}

\author{
HEIKKI MÄKIPÄÄ
}

\begin{abstract}
MÄKIPÄA, HEIKKI 1979: Crystallization history of some postmetamorphic diabases in Åland, Häme and Satakunta, Finland. A theoretical and experimental study. Bull. Geol. Soc. Finland 51, $93-124$.

The crystallization history of ten diabase dykes from three different sets in southern Finland are described.

The most primitive diabase magma can be derived from partially melted mantle. Evolving these magmas in the crust under different crystallization conditions the relationships between individual dykes can be explained.

The intrusion temperature has been derived to be about $1140-1170{ }^{\circ} \mathrm{C}$ and no clear distinction between individual sets can be made.

The results reveal that phenocrysts and megacrysts already were in the magma before intrusion. In the narrow dykes (width less than $3 \mathrm{~m}$ ) the cooling was so rapid that the phenocrysts had not time enough to reequilibrate.

The mega- and phenocryst concentration in the middle of the dyke is explained by flowage differentiation.
\end{abstract}

Heikki Mäkipää 1: Nordic Volcanological Institute, University of Iceland, Geoscience Building, 101 Reykjavik. Iceland.

\section{CONTENTS}

Abstract $\ldots \ldots \ldots \ldots \ldots \ldots \ldots \ldots \ldots \ldots \ldots \ldots \ldots \ldots$

Introduction $\ldots \ldots \ldots \ldots \ldots \ldots \ldots \ldots \ldots \ldots \ldots \ldots$

General remarks $\ldots \ldots \ldots \ldots \ldots \ldots \ldots$

Experiments $\ldots \ldots \ldots \ldots \ldots \ldots \ldots \ldots \ldots$

Mineral composition of the dikes $\ldots \ldots \ldots \ldots 96$

Analytical results

Aland diabases

Husö .................... 101

Bergskär, Betesö and Källsholm ....... 101

Häme diabases

Vehkajärvi ..................... 102

Orivesi I, II and III .............. 103

1 Present address: Geological Survey of Finland Box 237, SF-70101 Kuopio 10
Satakunta diabases

Kiperjärvenoja ................. 104

Hinnerjoki I and II ........... 105

Discussion

Chemical compositions ............... 105

Pressure-temperature relations ......... 106

Phase-equilibrium ................. 109

Cooling rate and crystallization history

Cooling rates .................. 110

Contact phenomena .............. 113

Duration of the solidification ......... 115

Settling of the plagioclase crystals ..... 116

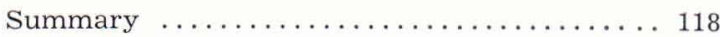

References $\ldots \ldots \ldots \ldots \ldots \ldots \ldots \ldots \ldots \ldots$

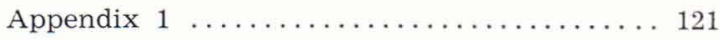

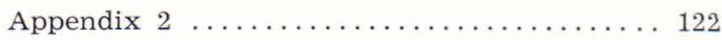

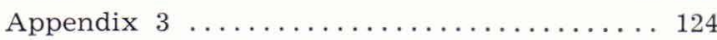




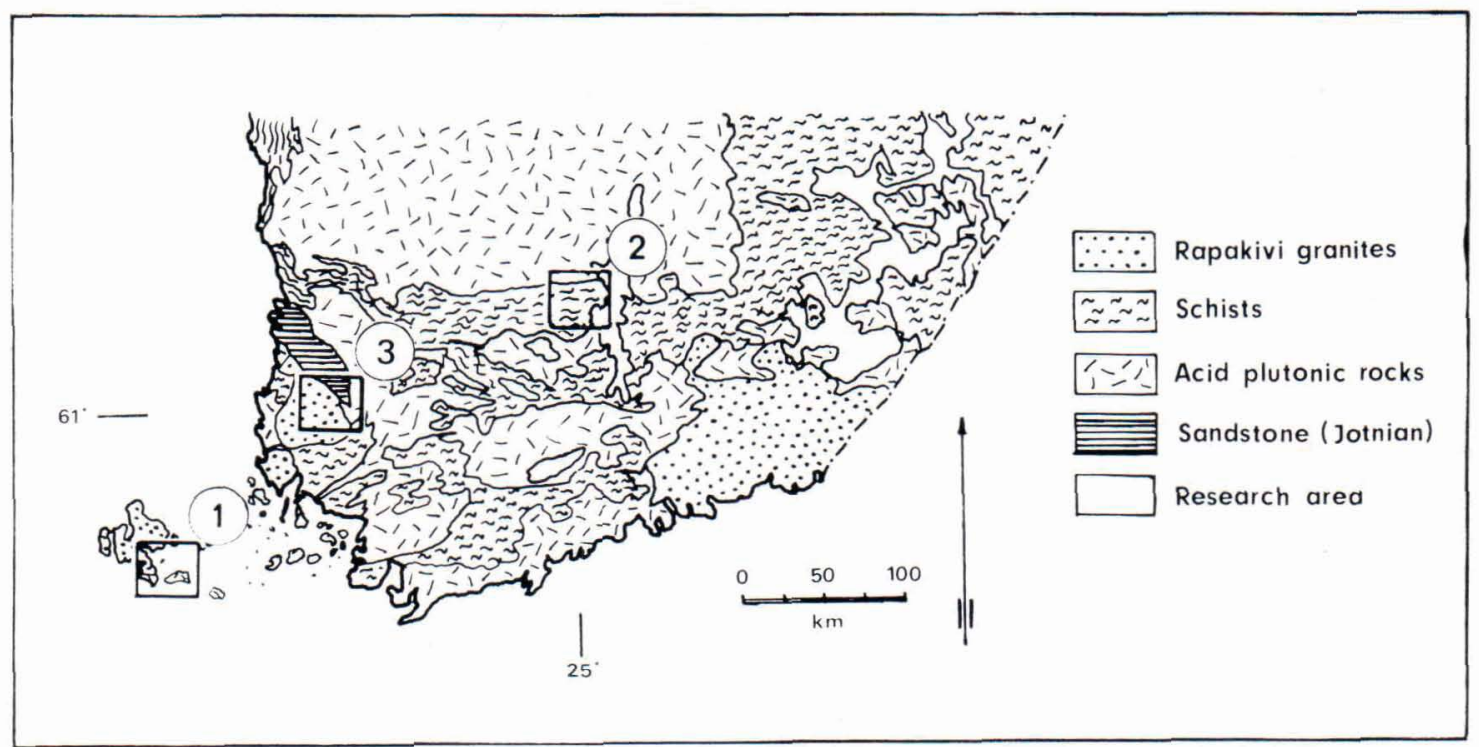

Fig. 1. Location of studied diabase sets and the bedrock of southern Finland (simplified after A. Simonen 1959). 1 - Aland diabase set, 2 - Häme diabase set, 3 - Satakunta diabase set.

\section{Introduction}

The present paper describes the crystallization history of three different sets of diabase dykes in southern Finland (Fig. 1). The dykes are much younger than the last metamorphism in southern Finland, which took place about $1900 \mathrm{Ma}$ ago. According to Ehlers and Ehlers (1977) the diabases of Aland archipelago are of the same age as the Aland rapakivi granite (1650 $\mathrm{Ma}$ according to Vaasjoki 1978). According to Laitakari, I. (1969) the
Häme diabase dykes are of the same age, while Satakunta diabases are much younger, about $1260 \mathrm{Ma}$ (Haapala 1977). The alteration found in these dykes is a slight weathering near the margins, the occurrence of secondary minerals is scarce.

A general view of the geology of Aland area is presented by Sederholm (1934). The diabases are recently described by Ehlers and Ehlers (1977). All sites of collected samples are located east of the rapakivi area. The nearest dyke, Källsholm, is about $11 \mathrm{~km}$ from

Table 1. Localities and widths of the studied diabase dykes.

\begin{tabular}{|c|c|c|c|c|}
\hline Diabase set & Map sheet 1 & Coordinates 1 & Name of locality & Width $(\mathrm{m})$ \\
\hline \multirow[t]{4}{*}{ Aland } & 101411 & $6661.78-490.42$ & Bergskär & 4.60 \\
\hline & 101411 & $6661.70-490.12$ & Husö & 0.17 \\
\hline & 101408 & $6662.92-483.87$ & Betesö & 1.00 \\
\hline & 101404 & $6659.20-479.40$ & Källsholm & $>100$ \\
\hline \multirow[t]{4}{*}{ Häme } & 214205 & $6840.10-514.86$ & Orivesi I & 0.26 \\
\hline & 214204 & $6839.74-514.38$ & Orivesi II & 1.20 \\
\hline & 214204 & $6837.22-511.40$ & Orivesi III & 5.10 \\
\hline & 214303 & $6822.40-544.75$ & Vehkajärvi & 3.10 \\
\hline \multirow[t]{3}{*}{ Satakunta } & 113306 & $6765.26-553.86$ & Hinnerjoki I & 0.25 \\
\hline & 113306 & $6765.26-553.86$ & Hinnerjoki II & 0.60 \\
\hline & 113407 & $6874.18-562.00$ & Kiperjärvenoja & $>60$ \\
\hline
\end{tabular}

1 Map sheet numbers and coordinates refer to the Finnish basic map system. 
the rapakivi contact. The dykes form sharp, sometimes wriggling, contacts with the gneissoic granodiorite country rock.

The width of the studied dykes (Table 1) varies from $17 \mathrm{~cm}$ to over $100 \mathrm{~m}$. Husö dyke (Fig. 2) is the narrowest one, and it contains large plagioclase megacrysts $(\sim 1 \mathrm{~cm})$ in the middle.

The Häme diabase set is about $150 \mathrm{~km}$ long and $20 \mathrm{~km}$ wide. According to Laitakari, I. (1966, 1969), more than one hundred individual dykes have been sofar found in the area. The size of the dykes varies but most of them are $5-50 \mathrm{~m}$ wide and several kilometres long.

The Vehkajärvi dyke (Fig. 3) is situated in the middle of the diabase set and is only 3.1 $m$ wide. It is ideally exposed in a road cutting. The diabase contains in the middle of the dyke large (up to $10 \mathrm{~cm}$ ) white plagioclase megacrysts.

The Satakunta diabase set was studied intensively in the beginning of this century

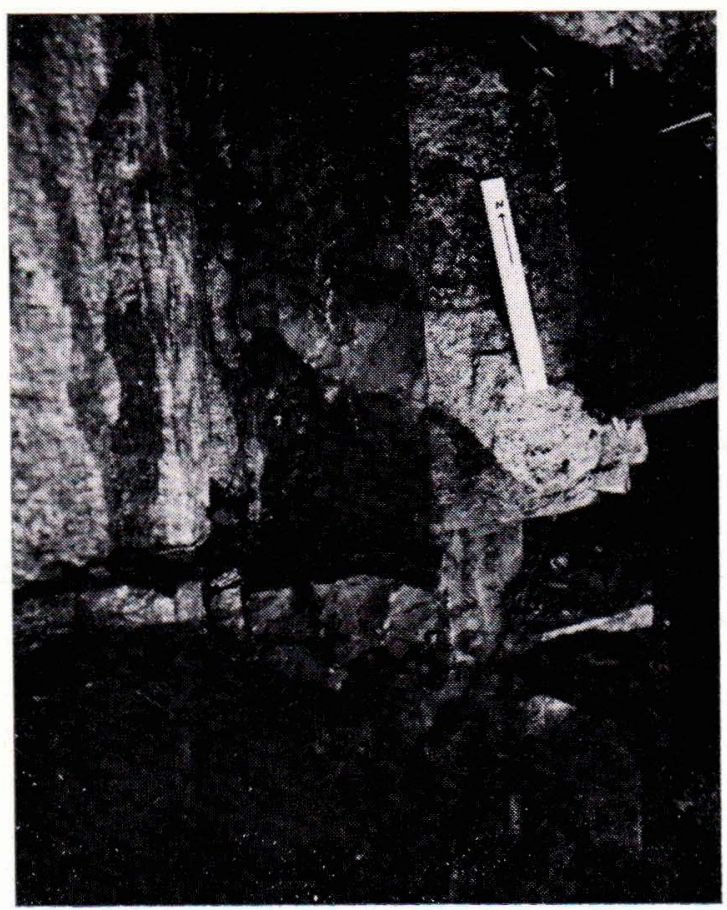

Fig. 2. Diabase dyke in Husö, Sottunga, Åland. Width $17 \mathrm{~cm}$.

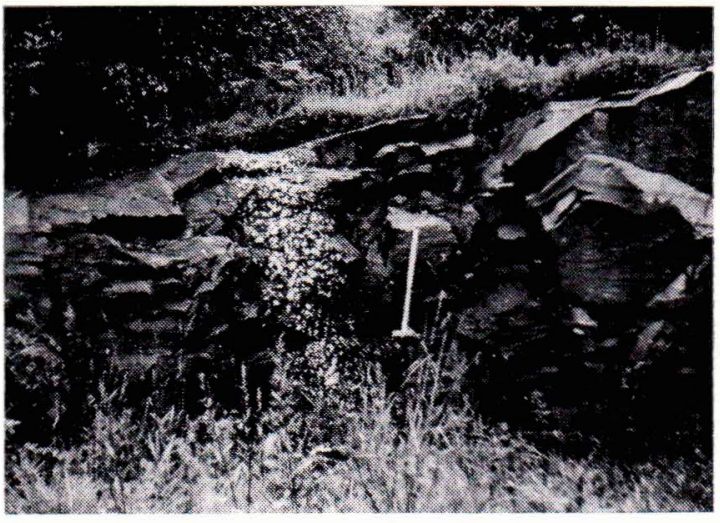

Fig. 3. A general view of the $3.1 \mathrm{~m}$ wide diabase dyke in Vehkajärvi, Häme. Note the zone of megacrysts on the left of the hammer.

(e.g., Sederholm, 1911; Laitakari, A., 1925, 1928). It is about $100 \mathrm{~km}$ long and $50 \mathrm{~km}$ wide. The width of the dykes varies from centimetres to several hundred metres.

One sample set is collected in the northern end of the Lake Pyhäjärvi at Kiperjärvenoja. The Kiperjärvenoja diabase forms an wriggling contact with Jotnian sandstone. The contact zone is well exposed in an about 3-10 $m$ deep drainage channel of Lake Kiperjärvi The samples were collected beginning from the contact and extending $60 \mathrm{~m}$ into the dyke. The minerals found as phenocrysts or megacrysts are plagioclase and occasional completely altered olivine. The contact phenomena are described by Laitakari, A. (1925) and Kahma (1951).

The purpose of this paper is to answer the following questions: What is the origin of the diabase magma and can all the dykes be derived from the same parental magma? Is there a genetic relationship between the diabase magma and the associated rapakivis? Is the diabase dyke chemistry affected by melted country rock? How fast did the dykes cool? To answer these questions the temperature of the intruding magma and the equilibrium between liquids and crystals must be established. 


\section{General remarks}

Table 1 gives the locations of the studied dykes. Their width is given in smaller dykes with great accuracy but in the largest ones only approximately according to field observations. The length of the dykes is always uncertain, owing the scarcity of the outcrops, but it can vary from hundreds to several thousand metres.

All analyses were carried out on an automatic ARL-SEMQ microprobe and the analytical procedures are described e.g. by Mäkipää (1978a). The $\mathrm{Fe}_{2} \mathrm{O}_{3} / \mathrm{FeO}$ ratio is calculated using $\mathrm{Fe}_{2} \mathrm{O}_{3} / \mathrm{FeO}-\mathrm{fo}_{2}$ relation (Mäkipää 1979).

According to the classification of Irvine \& Baragar (1971) all the rocks are quartz or olivine normative tholeiites.

\section{Experiments}

Several experimental runs were conducted at $1 \mathrm{~atm}$ using the vertical quench furnace to test the cooling rates of the dykes. Also the contamination of the wall rock was studied using the method described by Yoder (1973). However, all the experiments were carried out under dry conditions.

All the cooling rate experiments were performed using one dyke material of each studied diabase set. The powdered sample was suspended in a Pt loop at about $1200^{\circ} \mathrm{C}$ for 1 hour. The temperature, which is substantially higher than the liquidus of the dikes, was then decreased continuously and the rate of the cooling was varied between $2^{\circ} \mathrm{C} / \mathrm{h}$ and $300^{\circ} \mathrm{C} / \mathrm{h}$. The cooling rate was then correlated with the width of the plagioclase (010) pinacoid.

For miscibility tests of basalt and country rock the same dyke materials were used. The platinum tubes, which were presaturated with the same material, were packed end-to-end by powdered material of the dyke and powdered or solid rock of the country rock in question.

The capsule was then suspended horizontally into the furnace at $1200^{\circ} \mathrm{C}$ for one to several hours depending on the width of the natural dike. Then the temperature was decreased gradually at different speeds below the solidus. The products were then analyzed on the microprobe.

\section{Mineral composition of the dykes}

The observed crystals were divided into four categories depending on size. All the dykes contain (1) megacrysts (including cognate crystals as well as fragments) ranging from several centimetres up to 30 centimetres along the longest axis. Phenocrysts (2) are usually $0.5-0.2 \mathrm{~mm}$ long. Some dykes contain

Table 2. Partial mineral composition of the studied diabases. (Determined by the point-counting method). Pl-plagioclase, Ol-olivine, Px-pyroxene, Amph-amphipole Biot-biotite, Opaq-opaque, Qz-quartz

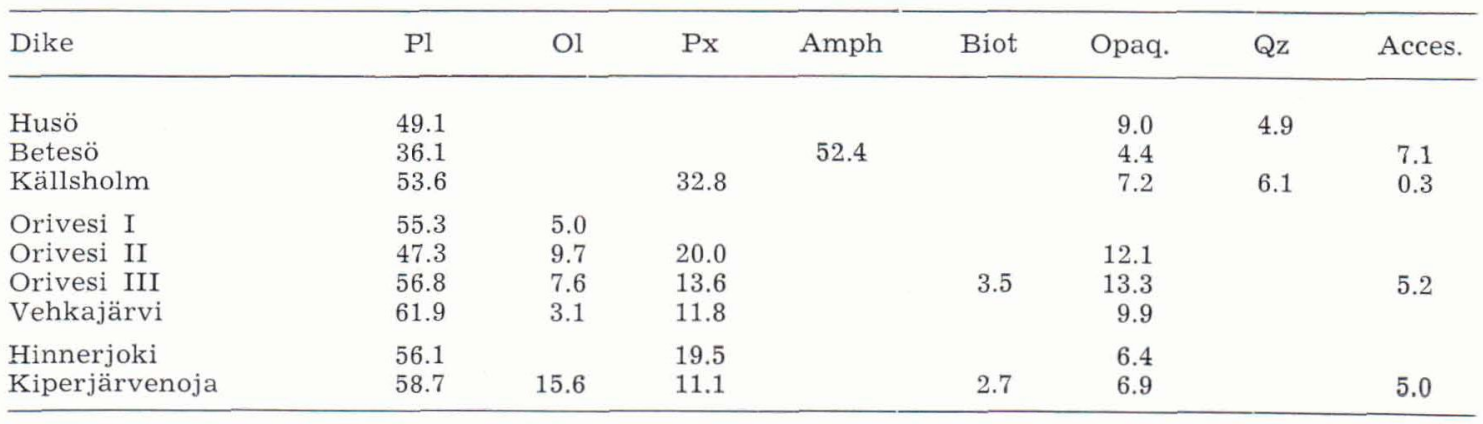




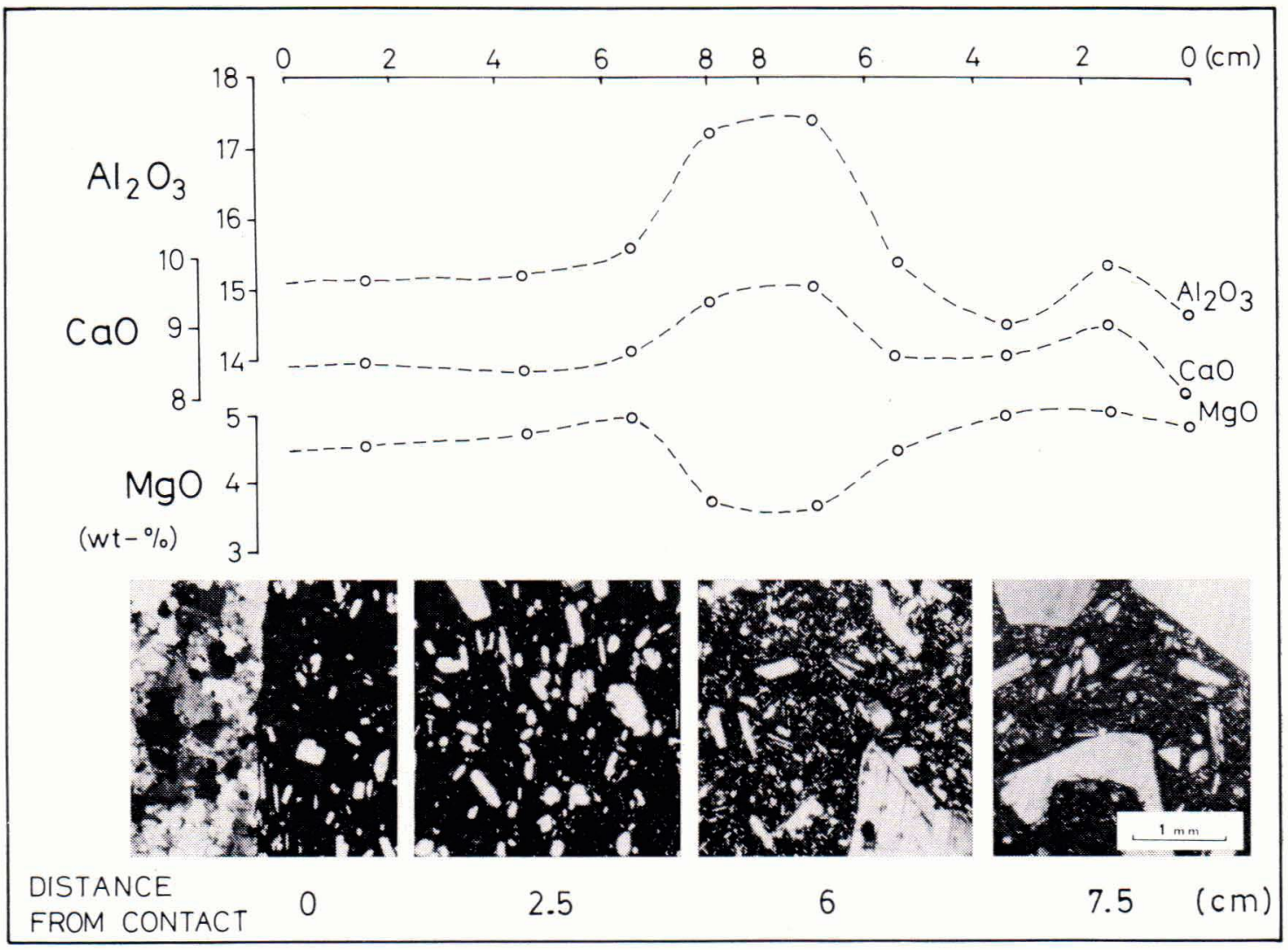

Fig. 4. $\mathrm{Al}_{2} \mathrm{O}_{3}, \mathrm{CaO}$ and $\mathrm{MgO}$ variation (total analyses) and the variation of the grain size of the dyke in Husö, Sottunga, Aland. The numbers given below the photos refer to the distances irom the contact. The scale is the same in all the photos.

also microphenocrysts (3) which are slightly larger than the groundmass minerals (4).

The partial modal compositions of the studied dykes are given in Table 2. Because of the narrowness of some dykes the groundmass was so glassy that the counting of the minerals was impossible, and therefore Table 2 gives rather the first primary phenocrysts found. The principal mineral is plagioclase, which comprises about $50 \%$ of the total volume of the rocks.

The diabases of the Aland area have variable mineral composition. Källsholm dyke is a pyroxene diabase while Husö, Betesö and Bergskär dykes are amphibole diabases. Amphibole is the dominant mineral. It is partially a secondary product. The few observed olivines are altered to opaque and serpentine, plagioclases to chlorite and epidote etc. This means that these three dykes, which are much older than the Källsholm dyke (V. Suominen, pers. comm.), have undergone a slight metamorphism. However, the contacts are still glassy and not recrystallized. In contrast the Källsholm diabase is rather fresh, although some secondary chlorite and amphibole occur.

The Häme and Satakunta diabases are olivine diabases. The dominant mineral is plagioclase, olivine occurs as idiomorphic grains sometimes with serpentine as alteration product. However, the occurrence of secondary minerals is very rare. 
Table 3. Chemical composition and CIPW norms of the diabase studied dykes and some closely related rocks. Microprobe analyses.

\begin{tabular}{|c|c|c|c|c|c|c|c|c|c|c|c|c|c|c|c|c|}
\hline \multirow{3}{*}{$\begin{array}{l}\text { Diabase set } \\
\text { Dyke } \\
\text { Column No. }\end{array}$} & \multicolumn{8}{|c|}{ ÅLAND } & \multicolumn{8}{|c|}{ HÄME } \\
\hline & \multicolumn{2}{|c|}{ Husö } & \multicolumn{2}{|c|}{ Bergskär } & \multicolumn{2}{|c|}{ Betesö } & \multicolumn{2}{|c|}{ Källsholm } & \multicolumn{2}{|c|}{ Orivesi I } & \multicolumn{2}{|c|}{ Orivesi II } & \multicolumn{2}{|c|}{ Orivesi III } & \multicolumn{2}{|c|}{ Vehkajärvi } \\
\hline & 1 & 2 & 1 & 2 & 1 & $2^{1}$ & 1 & 2 & 1 & 2 & 1 & 22 & 1 & 2 & 1 & 2 \\
\hline $\mathrm{SiO}_{2}$ & 53.90 & 53.42 & 53.51 & 54.58 & 49.08 & 47.61 & 52.21 & 51.22 & 49.61 & 49.94 & 50.86 & 50.92 & 47.62 & 49.24 & 51.41 & 51.32 \\
\hline $\mathrm{TiO}_{2}$ & 1.87 & 1.75 & 1.53 & 1.57 & 1.10 & 0.91 & 1.71 & 1.62 & 2.43 & 2.74 & 2.38 & 2.58 & 3.51 & 2.68 & 3.01 & 2.56 \\
\hline $\mathrm{Al}_{2} \mathrm{O}_{3}$ & 15.33 & 13.74 & 14.69 & 13.33 & 15.25 & 13.61 & 15.92 & 16.00 & 18.23 & 15.33 & 14.68 & 16.48 & 14.93 & 15.41 & 14.71 & 15.42 \\
\hline $\mathrm{Fe}_{2} \mathrm{O}_{3}$ & 3.29 & 3.35 & 3.58 & 3.68 & 2.52 & 1.32 & 3.20 & 3.58 & 3.88 & 3.68 & 4.11 & 2.40 & 3.85 & 3.22 & 3.55 & 3.81 \\
\hline $\mathrm{FeO}$ & 9.05 & 9.91 & 9.87 & 8.61 & 10.21 & 10.92 & 10.08 & 9.87 & 8.49 & 9.34 & 10.41 & 11.65 & 12.15 & 9.94 & 10.43 & 8.42 \\
\hline $\mathrm{MnO}$ & 0.15 & 0.21 & 0.16 & 0.18 & 0.13 & 0.27 & 0.15 & 0.13 & 0.12 & 0.20 & 0.18 & 0.10 & 0.15 & 0.17 & 0.16 & 0.18 \\
\hline $\mathrm{MgO}$ & 4.63 & 4.80 & 5.37 & 4.51 & 7.97 & 10.97 & 4.75 & 5.50 & 3.55 & 4.00 & 4.02 & 5.12 & 4.72 & 4.25 & 3.88 & 3.27 \\
\hline $\mathrm{CaO}$ & 8.05 & 8.05 & 7.42 & 8.52 & 9.28 & 10.06 & 7.41 & 7.60 & 8.59 & 7.62 & 8.02 & 5.98 & 8.16 & 7.43 & 6.85 & 7.30 \\
\hline $\mathrm{Na}_{2} \mathrm{O}$ & 2.30 & 2.37 & 2.50 & 2.48 & 2.48 & 2.62 & 2.76 & 2.61 & 2.85 & 2.90 & 2.30 & 2.52 & 2.65 & 3.01 & 2.57 & 3.36 \\
\hline $\mathrm{K}_{2} \mathrm{O}$ & 0.97 & 0.93 & 0.78 & 1.11 & 1.32 & 1.26 & 1.46 & 1.52 & 1.82 & 1.78 & 2.16 & 1.51 & 1.74 & 2.04 & 2.23 & 1.99 \\
\hline $\mathrm{P}_{2} \mathrm{O}_{5}$ & 0.48 & 0.43 & 0.45 & 0.39 & 0.27 & 0.40 & 0.43 & 0.60 & 0.49 & 0.76 & 0.64 & 0.78 & 0.76 & 0.73 & 0.88 & 0.84 \\
\hline Total & 100.02 & 98.96 & 99.86 & 98.96 & 99.61 & 100.02 & 100.08 & 100.26 & 100.06 & 98.29 & 99.76 & 100.04 & 100.25 & 98.12 & 99.68 & 98.47 \\
\hline No. of anal. & 12 & 154 & 10 & 14 & 6 & 18 & 10 & 10 & 12 & 16 & 11 & 8 & 9 & 10 & 14 & 109 \\
\hline \multicolumn{17}{|c|}{ CIPW norms (recalculated to $100 \%$ ) } \\
\hline $\mathrm{Qz}$ & 10.72 & 9.91 & 9.05 & 11.19 & - & - & 4.31 & 2.99 & 1.53 & 3.65 & 4.98 & 5.25 & - & 0.58 & 6.05 & 4.32 \\
\hline Or & 5.73 & 5.55 & 4.62 & 6.63 & 7.83 & 7.44 & 8.62 & 8.96 & 10.75 & 10.70 & 12.79 & 8.95 & 10.26 & 12.29 & 13.22 & 11.94 \\
\hline $\mathrm{Ab}$ & 19.46 & 20.27 & 21.18 & 21.21 & 21.07 & 16.76 & 23.34 & 22.03 & 24.10 & 24.97 & 19.51 & 21.31 & 22.37 & 25.96 & 21.82 & 28.87 \\
\hline An & 28.63 & 24.36 & 26.60 & 22.19 & 26.68 & 21.34 & 26.72 & 27.38 & 31.56 & 23.96 & 23.41 & 24.56 & 23.67 & 22.94 & 22.09 & 21.44 \\
\hline (Wo & 3.41 & 5.49 & 3.06 & 7.49 & 7.42 & 10.83 & 3.01 & 2.64 & 3.27 & 3.94 & 5.13 & - & 4.92 & 4.08 & 2.60 & 4.08 \\
\hline Di En & 1.70 & 2.60 & 1.52 & 3.78 & 4.06 & 6.24 & 1.40 & 1.33 & 1.63 & 1.94 & 2.31 & - & 2.26 & 1.93 & 1.18 & 1.97 \\
\hline IFs & 1.64 & 2.82 & 1.47 & 3.54 & 3.09 & 4.10 & 1.58 & 1.24 & 1.58 & 1.93 & 2.79 & - & 2.62 & 2.09 & 1.41 & 2.04 \\
\hline Hy $\{\mathrm{En}$ & 9.83 & 9.48 & 11.87 & 7.57 & 6.40 & - & 10.42 & 12.33 & 7.21 & 8.20 & 7.73 & 12.75 & 8.62 & 8.86 & 8.52 & 6.30 \\
\hline $11 y$ Fs & 9.46 & 10.25 & 11.48 & 7.08 & 4.87 & - & 11.74 & 11.46 & 7.01 & 8.20 & 9.36 & 15.33 & 9.98 & 9.61 & 10.18 & 6.51 \\
\hline $\mathrm{Ol}\{\mathrm{Fo}$ & - & - & - & - & 6.63 & 14.77 & - & - & - & - & - & - & 0.60 & - & - & - \\
\hline IFa & - & - & - & - & 5.56 & 10.70 & - & - & - & - & - & - & 0.76 & - & - & - \\
\hline Mt & 4.76 & 4.91 & 5.20 & 5.39 & 3.67 & 1.92 & 4.63 & 5.18 & 5.62 & 5.43 & 5.98 & 3.48 & 5.57 & 4.76 & 5.16 & 5.61 \\
\hline Il & 3.55 & 3.36 & 2.91 & 3.01 & 2.10 & 1.73 & 3.24 & 3.07 & 4.61 & 5.29 & 4.53 & 4.90 & 6.65 & 5.19 & 5.73 & 4.94 \\
\hline Ap & 1.11 & 1.01 & 1.04 & 0.91 & 0.63 & 0.93 & 0.10 & 1.39 & 1.13 & 1.79 & 1.49 & 1.81 & 1.76 & 1.72 & 2.05 & 1.98 \\
\hline
\end{tabular}


Table 3 (continued)

\begin{tabular}{|c|c|c|c|c|c|c|c|c|c|c|}
\hline \multirow{2}{*}{$\begin{array}{l}\text { Diabase set } \\
\text { Dyke }\end{array}$} & \multicolumn{4}{|c|}{ SATAKUNTA } & \multicolumn{6}{|c|}{ SOME CLOSELY RELATED ROCKS } \\
\hline & \multicolumn{2}{|c|}{ Kiperjärvenoja } & \multicolumn{2}{|c|}{ Hinnerjoki } & \multirow[b]{2}{*}{3} & \multirow[b]{2}{*}{4} & \multirow[b]{2}{*}{5} & \multirow[b]{2}{*}{6} & \multirow[b]{2}{*}{7} & \multirow[b]{2}{*}{$8^{4}$} \\
\hline Column No. & 1 & 2 & 1 & $2^{3}$ & & & & & & \\
\hline $\mathrm{SiO}_{2}$ & 47.45 & 47.89 & 47.38 & 47.06 & 52.69 & 46.20 & 47.73 & 48.84 & 51.46 & 47.36 \\
\hline $\mathrm{TiO}_{2}$ & 2.91 & 2.59 & 2.75 & 2.46 & 1.14 & 1.90 & 1.96 & 3.78 & 1.95 & 1.00 \\
\hline $\mathrm{Al}_{2} \mathrm{O}_{3}$ & 16.99 & 17.49 & 18.81 & 18.39 & 14.12 & 17.20 & 15.06 & 12.70 & 15.35 & 19.70 \\
\hline $\mathrm{Fe}_{2} \mathrm{O}_{3}$ & 3.19 & 3.11 & 3.61 & 2.26 & 3.32 & 2.08 & 4.09 & 5.12 & 1.53 & 0.75 \\
\hline $\mathrm{FeO}$ & 10.52 & 8.56 & 9.93 & 8.52 & 9.49 & 11.95 & 10.40 & 9.47 & 12.39 & 10.46 \\
\hline $\mathrm{MnO}$ & 0.17 & 0.10 & 0.11 & 0.16 & 0.22 & 0.29 & 0.20 & 0.19 & 0.10 & 0.14 \\
\hline $\mathrm{MgO}$ & 5.13 & 4.90 & 5.54 & 4.86 & 5.53 & 7.10 & 4.23 & 4.32 & 4.42 & 8.34 \\
\hline $\mathrm{CaO}$ & 8.50 & 7.10 & 7.46 & 6.61 & 9.86 & 8.98 & 10.48 & 7.26 & 7.32 & 8.77 \\
\hline $\mathrm{Na}_{2} \mathrm{O}$ & 3.07 & 3.07 & 2.94 & 3.09 & 2.51 & 2.88 & 2.74 & 2.76 & 2.94 & 2.68 \\
\hline $\mathrm{K}_{2} \mathrm{O}$ & 1.37 & 1.36 & 1.37 & 1.04 & 0.64 & 0.89 & 1.46 & 1.96 & 1.64 & 0.63 \\
\hline $\mathrm{P}_{2} \mathrm{O}_{5}$ & 0.56 & 0.55 & 0.43 & 0.37 & - & 0.01 & 0.35 & 1.19 & 0.79 & 0.15 \\
\hline Total & 99.86 & 96.72 & 100.33 & 94.82 & 99.52 & 99.48 & 98.70 & 97.59 & 99.87 & 99.98 \\
\hline No of anal. & 10 & 15 & 8 & 14 & & & & & 3 & \\
\hline \multicolumn{11}{|c|}{ CIPW norms (recalculated to $100 \%$ ) } \\
\hline $\mathrm{Qz}$ & - & 0.11 & - & & 5.36 & - & - & 6.02 & 1.23 & - \\
\hline Or & 8.05 & 8.31 & 8.07 & & 3.80 & 5.29 & 8.74 & 11.87 & 9.70 & 3.72 \\
\hline $\mathrm{Ab}$ & 26.02 & 26.86 & 24.80 & & 21.34 & 22.17 & 23.49 & 23.93 & 24.91 & 22.68 \\
\hline An & 28.60 & 30.94 & 33.97 & & 25.49 & 31.54 & 24.80 & 16.88 & 23.87 & 39.87 \\
\hline Wo & 4.16 & 0.74 & 0.05 & & 9.88 & 5.50 & 10.64 & 5.03 & 3.06 & 1.11 \\
\hline Di En & 2.08 & 0.41 & 0.03 & & 4.94 & 2.70 & 4.77 & 2.87 & 1.16 & 0.59 \\
\hline Fs & 1.99 & 0.30 & 0.02 & & 4.73 & 2.70 & 5.82 & 1.94 & 1.94 & 0.49 \\
\hline Hy $\{\mathrm{En}$ & 4.32 & 12.21 & 7.60 & & 8.90 & - & 2.46 & 8.15 & 9.86 & 2.35 \\
\hline Hy Y Fs & 4.12 & 9.07 & 6.02 & & 8.54 & - & 3.00 & 5.51 & 16.50 & 1.95 \\
\hline Ol $\{\mathrm{Fo}$ & 4.48 & - & 4.29 & & - & 10.56 & 2.41 & - & - & 12.50 \\
\hline $\mathrm{O} / \mathrm{Fa}$ & 4.71 & - & 3.74 & & - & 11.60 & 3.24 & - & - & 11.40 \\
\hline Mt & 4.63 & 4.66 & 5.21 & & 4.84 & 3.03 & 6.01 & 7.61 & 2.22 & 1.09 \\
\hline Il & 5.53 & 5.09 & 5.21 & & 2.18 & 3.63 & 3.77 & 7.36 & 3.71 & 1.90 \\
\hline Ap & 1.30 & 1.32 & 0.99 & & - & 0.02 & 0.84 & 2.83 & 1.83 & 0.35 \\
\hline
\end{tabular}

\section{COLUMNS:}

1. Mean composition of the dyke

2. Average groundmass analysis.

3. High $\mathrm{Fe}_{2} \mathrm{O}_{3}$ quartz normative dolerite (Weigand \& Ragland, 1970).5

4. Olivine diabase, Sorkka, Rauma (Kahma 1951). The total in the original paper is 100.72 , containing $1.24 \%$ $\mathrm{H}_{2} \mathrm{O}^{t}$.

5. Olivine diabase, Suontaka, Laitila (Kahma, 1951). The total is in the original paper 100.15 , containing $1.45 \% \mathrm{H}_{2} \mathrm{O}^{\mathrm{t}}$.

6. Quartz diabase, Möykynsaari, Lake Ladoga (Lokka, 1934). The total is in the original paper 100.27 , containing $2.68 \% \mathrm{H}_{2} \mathrm{O}^{\mathrm{t}}$.

7. Quartz diabase, Kelesjärvi, Jaala (Savolahti, 1956). The total is in the original paper 100.47 , containing 0.60 $\% \mathrm{H}_{2} \mathrm{O}^{\mathrm{t}}$.

8. Olivine diabase, Ansio, Padasjoki (Savolahti, 1964). The total is in the original paper 100.44, containing

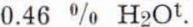

$13.25 \% \mathrm{Ne}$ in the norm

$1.69 \%$ Co in the norm.

3 Norm is not calculated because of the low total.

$41.26 \% \mathrm{Ne}$ in the norm.

5 In the original paper total Fe reported as $\mathrm{Fe}_{2} \mathrm{O}_{3}$, ratio calculated using the method described in Appendix 1. 
Table 4. Microprobe analyses of plagioclases, Husö, dyke, Åland.

\begin{tabular}{|c|c|c|c|c|c|c|c|c|c|c|c|c|c|c|c|c|}
\hline & \multicolumn{2}{|l|}{ I } & megacrysts & \multicolumn{2}{|r|}{1} & \multirow{2}{*}{$\begin{array}{c} \\
54.28\end{array}$} & \multicolumn{2}{|c|}{ phenocrysts } & \multicolumn{3}{|r|}{$\overline{1}$} & \multirow{2}{*}{$\begin{array}{c} \\
52.24\end{array}$} & \multicolumn{3}{|c|}{ groundmass plagioclase } & 7 \\
\hline & 58.98 & 54.53 & 53.57 & 55.03 & 53.95 & & 56.12 & 54.48 & 53.66 & 55.21 & 54.30 & & 55.26 & 53.67 & 53.39 & 54.20 \\
\hline $\mathrm{Al}_{2} \mathrm{O}_{3}$ & 25.80 & 28.17 & 28.71 & 28.12 & 28.19 & 27.67 & 27.26 & 28.20 & 28.52 & 27.47 & 27.91 & 28.27 & 27.52 & 28.01 & 28.25 & 27.51 \\
\hline $\mathrm{FeO}^{\mathrm{t}}$ & .30 & 1.06 & 1.02 & .37 & .84 & .78 & .57 & .73 & 1.12 & .74 & 1.18 & 1.19 & 1.18 & 1.35 & 1.16 & .62 \\
\hline $\mathrm{CaO}$ & 7.59 & 10.16 & 12.05 & 10.88 & 11.82 & 11.21 & 9.55 & 11.81 & 11.98 & 10.86 & 11.49 & 12.26 & 11.08 & 11.24 & 11.95 & 11.30 \\
\hline $\mathrm{Na}_{2} \mathrm{O}$ & 6.78 & 5.32 & 4.64 & 5.29 & 4.93 & 5.20 & 5.11 & 4.75 & 4.65 & 5.23 & 4.84 & 4.40 & 5.01 & 5.05 & 4.53 & 5.10 \\
\hline $\mathrm{K}_{2} \mathrm{O}$ & .62 & .09 & .17 & .29 & .10 & .22 & .59 & .12 & .19 & .19 & .18 & .15 & .18 & .13 & .16 & .17 \\
\hline Total & 100.07 & 99.33 & 100.16 & 99.98 & 99.93 & 99.36 & 99.20 & 100.09 & 100.12 & 99.70 & 99.90 & 98.51 & 100.23 & 99.45 & 99.44 & 98.90 \\
\hline An $\left(\right.$ mole $\left.^{-} \%\right)$ & 36.8 & 51.3 & 58.4 & 52.3 & 57.0 & 54.4 & 49.0 & 57.5 & 58.1 & 53.4 & 56.8 & 60.1 & 55.0 & 55.2 & 59.3 & 54.5 \\
\hline No of anal. & 4 & 2 & 3 & 3 & 4 & 8 & 2 & 4 & 4 & 4 & 5 & 3 & 4 & 6 & 2 & 7 \\
\hline $\begin{array}{l}\text { Dist. from } \\
\text { cont. (mm) }\end{array}$ & 90 & 90 & 90 & 75 & 75 & 10 & 33 & 33 & 80 & 30 & 30 & 15 & 90 & 75 & 50 & 20 \\
\hline $\begin{array}{l}\text { Calculated } \\
\text { density }\end{array}$ & 2.598 & 2.622 & 2.635 & 2.624 & 2.633 & 2.628 & 2.618 & 2.633 & 2.634 & 2.626 & 2.633 & 2.638 & 2.628 & 2.629 & 2.637 & 2.628 \\
\hline Notes & core $\stackrel{\text { sam }}{\longleftarrow}$ & $\begin{array}{l}\text { crystal } \\
\mathrm{mm}\end{array}$ & $\stackrel{\operatorname{rim}}{\longrightarrow}$ & $\begin{array}{l}\text { sam } \\
\text { core } \\
\leftarrow\end{array}$ & $\begin{array}{l}\text { crystal } \\
\stackrel{\mathrm{mm}}{\rightarrow} \rightarrow\end{array}$ & & $\begin{array}{l}\text { same } \mathrm{c} \\
\text { core }\end{array}$ & $\begin{array}{l}\text { ystal } \\
\rightarrow \text { rim }\end{array}$ & & $\begin{array}{l}\text { same } \\
\text { core - }\end{array}$ & $\begin{array}{l}\text { rystal } \\
\rightarrow \text { rim }\end{array}$ & & & & & \\
\hline
\end{tabular}

Table 5. Microprobe analyses of plagioclases, Vehkajärvi dyke.

\begin{tabular}{|c|c|c|c|c|c|c|c|c|c|c|c|c|c|c|c|c|}
\hline \multirow{7}{*}{$\begin{array}{l}\mathrm{SiO}_{2} \\
\mathrm{Al}_{2} \mathrm{O}_{3} \\
\mathrm{FeO} \\
\mathrm{CaO} \\
\mathrm{Na}_{2} \mathrm{O} \\
\mathrm{K}_{2} \mathrm{O}\end{array}$} & \multirow{2}{*}{$\begin{array}{c}\bar{I} \\
54.81\end{array}$} & \multicolumn{3}{|c|}{ megacrysts } & \multirow{2}{*}{\multicolumn{2}{|c|}{$\begin{array}{c} \\
53.30\end{array}$}} & \multicolumn{2}{|c|}{ phenocrysts } & & & 1 & T & \multicolumn{4}{|c|}{ groundmass plagioclase } \\
\hline & & 54.85 & 54.92 & 55.27 & & & 53.82 & 54.32 & 54.41 & 55.11 & 54.78 & 53.40 & 55.03 & 55.61 & 55.20 & 58.22 \\
\hline & 28.54 & 28.84 & 28.73 & 28.61 & 26.12 & 29.62 & 29.48 & 28.31 & 28.19 & 28.16 & 28.35 & 29.40 & 28.14 & 27.81 & 27.59 & 26.17 \\
\hline & .39 & .35 & .43 & .33 & .77 & .61 & .66 & .57 & .73 & .82 & .48 & .75 & .54 & .85 & .82 & .54 \\
\hline & 11.12 & 10.73 & 10.67 & 10.69 & 7.66 & 11.83 & 11.13 & 10.80 & 11.33 & 10.28 & 10.55 & 11.24 & 10.48 & 10.38 & 9.94 & 8.12 \\
\hline & 4.86 & 4.78 & 4.87 & 4.91 & 6.12 & 4.32 & 4.52 & 4.65 & 4.76 & 5.17 & 5.11 & 4.79 & 4.99 & 5.14 & 5.18 & 6.61 \\
\hline & .66 & .69 & .64 & .58 & 1.31 & .49 & .55 & .67 & .60 & .65 & .60 & .52 & .77 & .68 & .65 & .60 \\
\hline Total & 100.38 & 100.24 & 100.28 & 100.39 & 100.00 & 100.17 & 100.16 & 99.32 & 100.02 & 100.19 & 99.87 & 100.10 & 99.95 & 100.47 & 99.38 & 100.26 \\
\hline An $($ mole- $\%$ o $)$ & 55.8 & 55.4 & 54.7 & 54.6 & 40.9 & 60.2 & 57.6 & 56.2 & 55.8 & 52.3 & 53.3 & 56.4 & 53.7 & 52.7 & 51.5 & 40.4 \\
\hline No of anal. & 2 & 2 & 2 & 2 & 2 & 4 & 2 & 4 & 4 & 2 & 2 & 6 & 3 & 3 & 2 & 2 \\
\hline $\begin{array}{l}\text { Dist. from } \\
\text { cont. }(\mathrm{cm})\end{array}$ & 152 & 152 & 152 & 152 & 152 & 0.1 & 0.1 & 1 & 34 & 50 & 152 & 0.1 & 35 & 50 & 152 & 152 \\
\hline $\begin{array}{l}\text { Calculated } \\
\text { density }\end{array}$ & 2.631 & 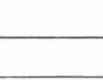 & 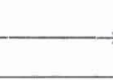 & $\rightarrow 2.628$ & 2.603 & 2.638 & 2.633 & 2.632 & 2.631 & 2.625 & 2.627 & 2.632 & 2.627 & 2.626 & 2.623 & 2.603 \\
\hline Notes & core & sam & $2 \mathrm{~cm}-$ & - & $\operatorname{rim}_{\rightarrow}$ & $\begin{array}{l}\text { same cr } \\
\text { core }- \\
\leftarrow 0.5 \mathrm{c}\end{array}$ & $\begin{array}{l}\text { ystal } \\
\rightarrow \text { rim } \\
m \rightarrow\end{array}$ & & & & & & core & & $\begin{array}{l}\text { same } \\
\text { core }- \\
\leftarrow 0.01\end{array}$ & $\begin{array}{c}\text { crystal } \\
\rightarrow \text { rim } \\
\mathrm{cm} \rightarrow\end{array}$ \\
\hline
\end{tabular}




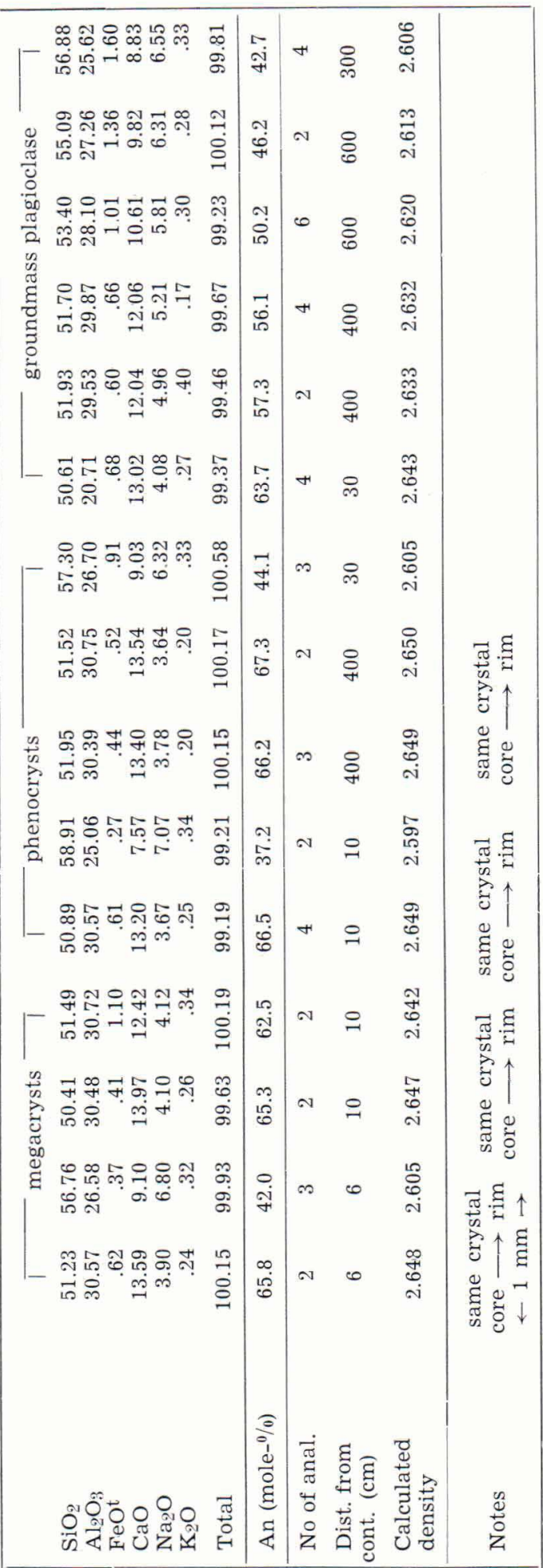

\section{Analytical results}

Aland diabases

$\mathrm{H}$ u s ö

The mean chemical composition of the dyke is that of a quartz normative tholeiite (Table 3 ). However, the composition of the individual samples through the whole dyke varies considerably (Fig. 4 and Appendix 1). Due to the strong plagioclase concentration (40\%) samples near the center of the dyke show marked increase in $\mathrm{CaO}, \mathrm{Al}_{2} \mathrm{O}_{3}$ and $\mathrm{Na}_{2} \mathrm{O}$, while $\mathrm{MgO}$, $\mathrm{FeO}^{\mathrm{t}}$ and $\mathrm{TiO}_{2}$ decrease.

Composition of groundmass through the whole dyke shows variation only (Fig. 5) at the contacts, which will be discussed later. The analyses are given in Appendix 2.

The plagioclase composition is given in Table 4. Some of the megacrysts $\left(\mathrm{An}_{38-53}\right)$ are extremely homogeneous while others show strong compositional zoning. The large megacrysts usually have an inner and outer rim of $\mathrm{An}_{50-53}$ and $\mathrm{An}_{54-59}$, respectively.

Plagioclase phenocrysts $\left(\mathrm{An}_{48-54}\right)$ are homogeneous with a very thin reaction rim, $\mathrm{An}_{54-59}$. The groundmass is wholly glassy about $8 \mathrm{~mm}$ from the contacts. The groundmass plagioclases $\left(\mathrm{An}_{55-60}\right)$ in the inner part of the dyke are extremely homogeneous laths.

Iron sulfides occur in $1-2 \mathrm{~mm}$ wide zones about $5 \mathrm{~mm}$ from the contacts. The concentration of sulfides in these zones is extremely high, up to 30 vol. $\%$.

B ergskär, B e te sö and

$\mathrm{K}$ ällsholm

The composition of the dykes are given in Table 3. The composition of individual dykes is very homogeneous except in the Källsholm dyke where variation can be observed.

The composition of Bergskär plagioclase phenocrysts and matrix plagioclases are $\mathrm{An}_{52-53}$ (rim $\mathrm{An}_{54-56}$ ) and $\mathrm{An}_{53-59}$, respectively. 


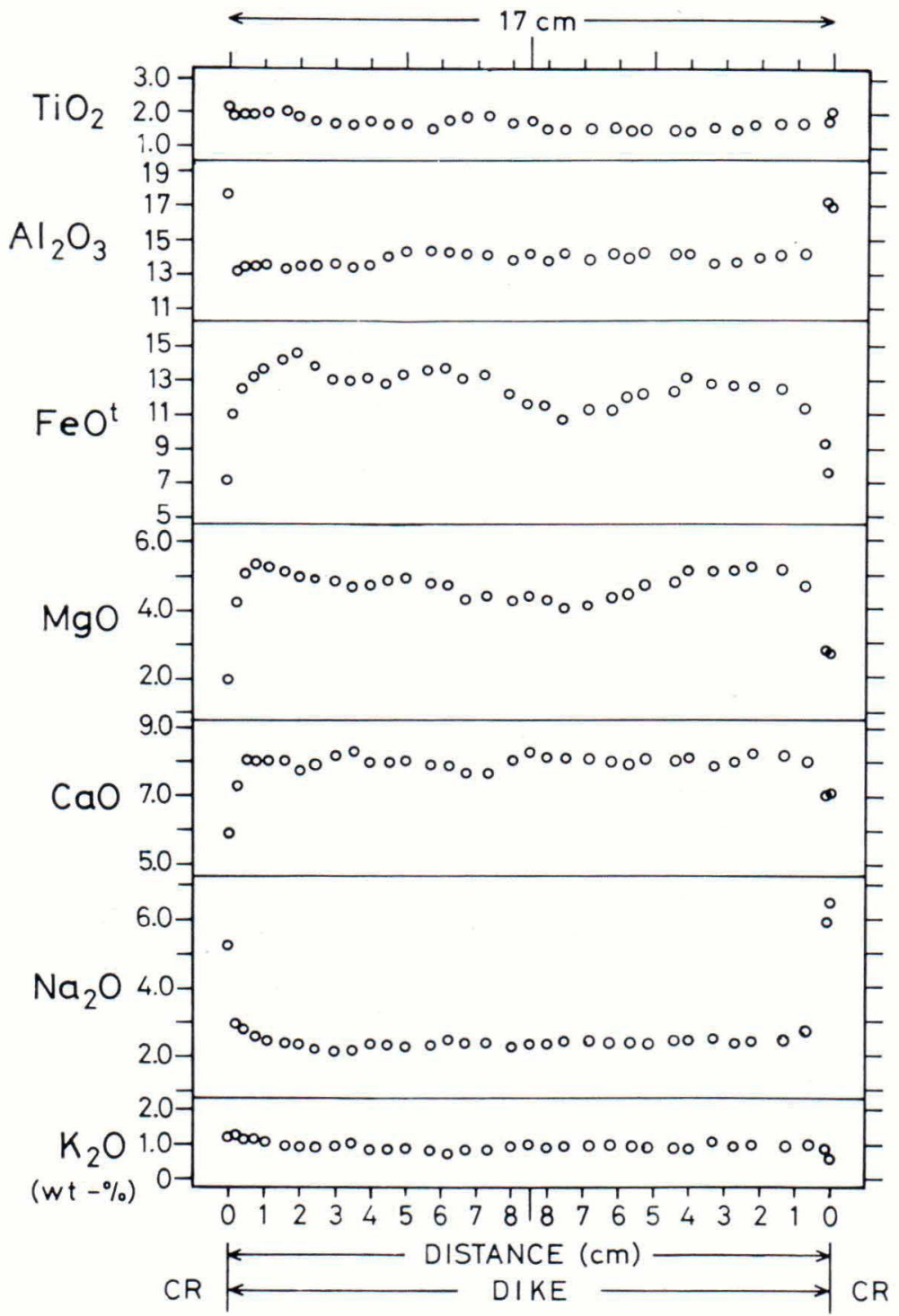

Fig 5. The groundmass chemistry variation (major elements) through the diabase dyke in Husö, Sottunga, Alland. Each circle is an average of many spot analyses given in Appendix

2. $\mathrm{CR}$ - country rock.
The corresponding values are $\mathrm{An}_{35-45}$ (rim $A n_{25-40}$ ), $A n_{34-47}$ for Betesö and $\mathrm{An}_{48-55}$ (rim $\left.\mathrm{An}_{45-55}\right), \quad \mathrm{An}_{47-77}$ Källsholm plagioclase phenocrysts and matrix plagioclases, respectively. All the plagioclase compositions are tabulated in Appendix 3.

Häme diabases

V e h k a järvi

The mean chemical composition of the dyke is that of a quartz normative tholeiite (Table
2). The variation in chemical composition through the dyke (Appendix 1) reflects concentration of plagioclase megacrysts, $\mathrm{CaO}$, $\mathrm{Al}_{2} \mathrm{O}_{3}$ (Fig. 6) and $\mathrm{Na}_{2} \mathrm{O}$ increase towards the middle of the dyke.

The groundmass chemistry (Table 3) is extremely homogenous until the plagioclase megacryst zone. Spot analyses of the groundmass through the whole dyke show strong variation in the megacryst zone (Fig. 7) re- 


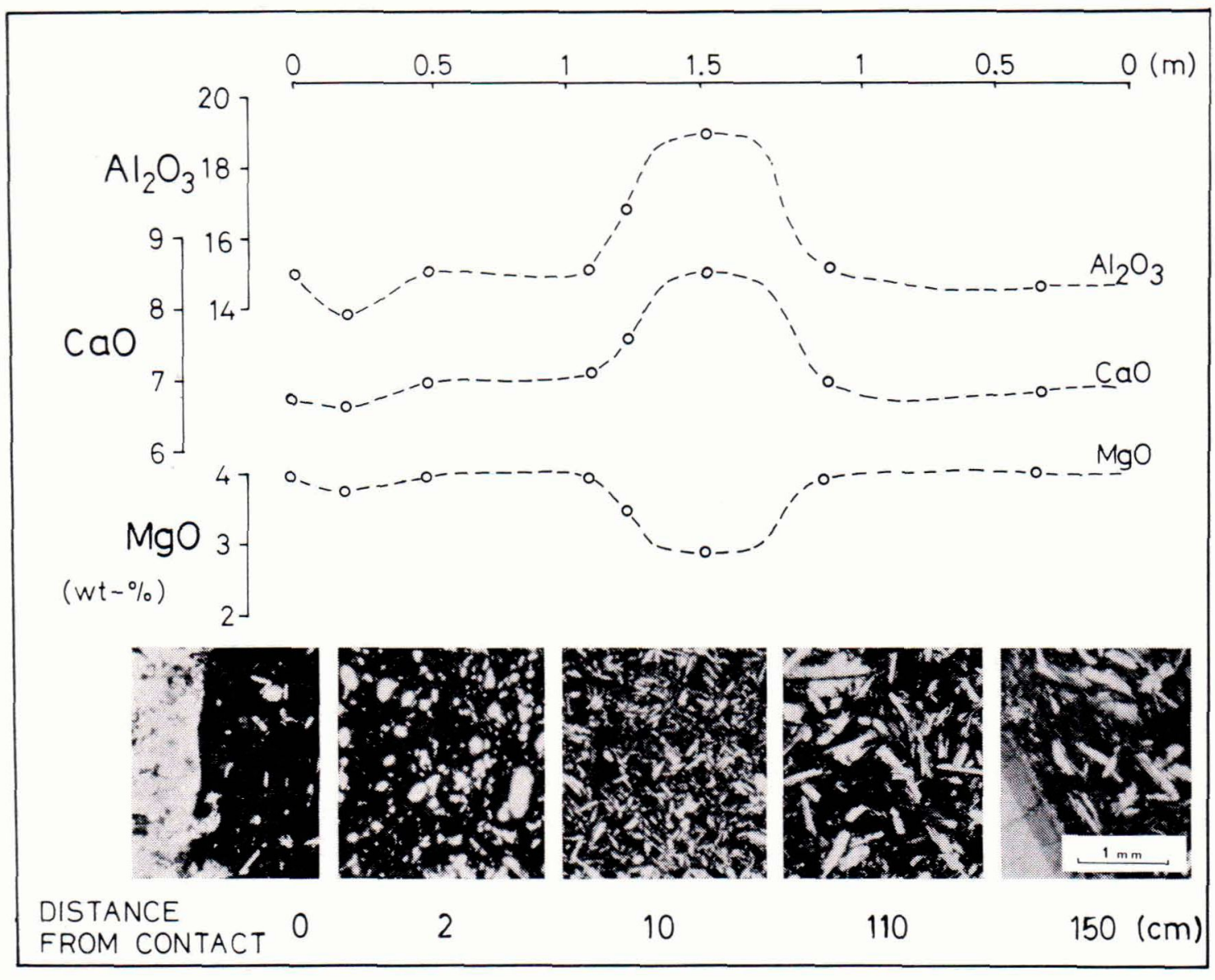

Fig. 6. $\mathrm{Al}_{2} \mathrm{O}_{3}, \mathrm{CaO}$ and $\mathrm{MgO}$ variation (total analyses) and the variation of the grain size of the dyke in Vehkajärvi, Häme. The numbers given below the photos refer to the distances from the contact. The scale is the same in all the photos.

flecting intense reaction between the megacrysts and the groundmass.

The plagioclase composition is given in Table 5. The large megacrysts are extremely homogenous $\left(\mathrm{An}_{55-58}\right)$ with a rim of $\mathrm{An}_{40-42}$. The crystallization of these $0.1 \mathrm{~mm}$ wide zones have caused significant in situ differentiation.

Plagioclase phenocrysts $\left(\mathrm{An}_{56-60}\right)$ are occasionally zoned with a thin reaction zone of $\mathrm{An}_{50-53}$. The groundmass is wholly glassy to about $5 \mathrm{~mm}$ from the contact. The matrix plagioclase composition is usually $\mathrm{An}_{52-56}$ but in the megacryst zone the composition is variable down to $\mathrm{An}_{40}$.

\section{Orivesi I, II and III}

The chemical composition of individual dykes is not the same (Table 3 ). Therefore it is assumed that they do not represent the same magmatic event.

The chemical composition through individual dykes is very constant and the dykes characteristically contain large plagioclase megacrysts (largest $10 \mathrm{~cm}$ ). Phenocrysts are plagioclase and occasionally pyroxenes which are frequently altered. Olivine is very rare.

The composition of plagioclase phenocrysts and matrix plagioclases is $\mathrm{An}_{54-65}$ and 


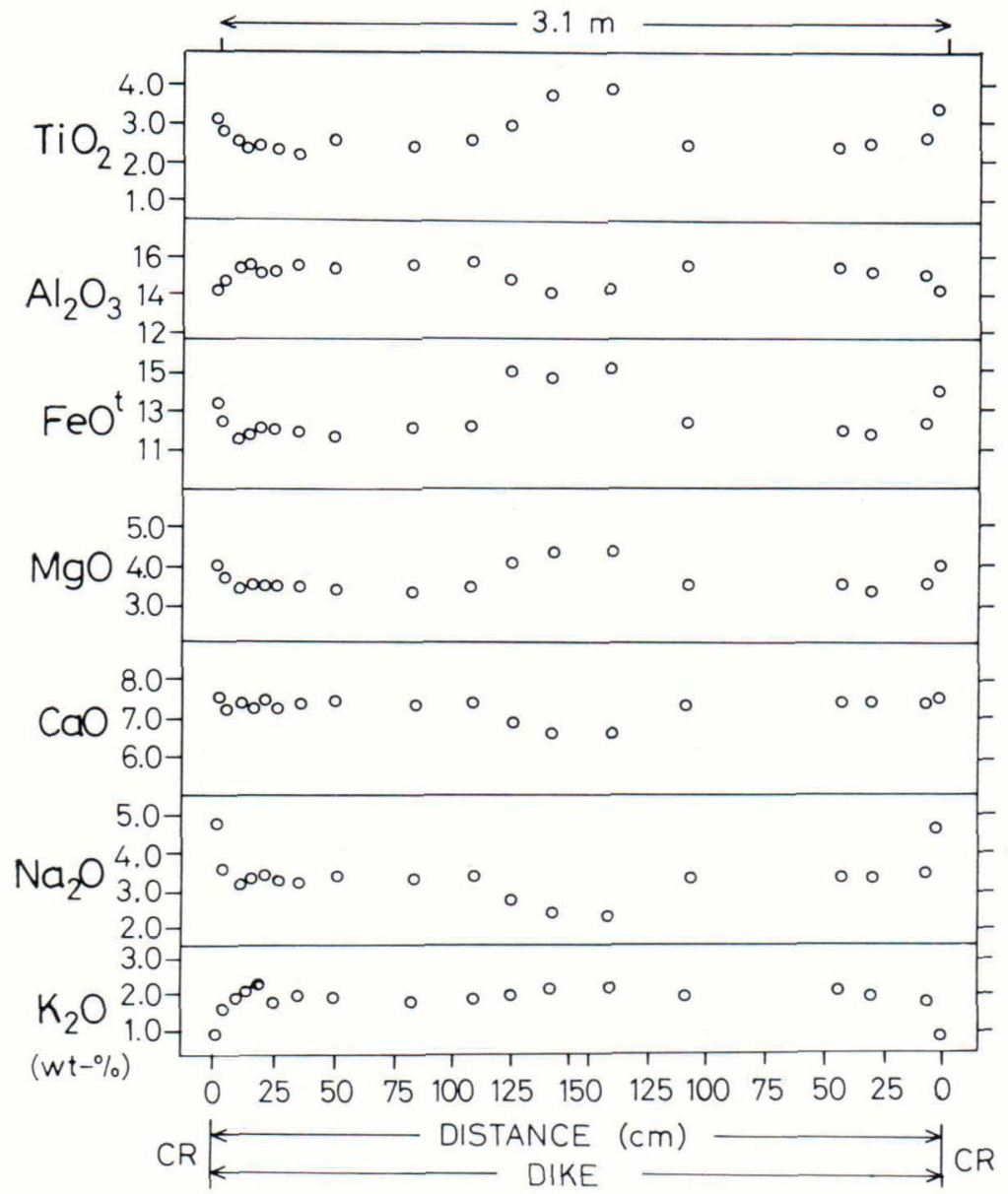

Fig. 7. The groundmass chemistry variation (major elements) through the diabase dyke in Vehkajärvi, Häme. Each circle is an average of many spot analyses given in Appendix 2. $\mathrm{CR}$ - country rock.
$\mathrm{An}_{51-60}$, respectively. The plagioclase compositions of individual dykes are tabulated in Appendix 4.

\section{Satakunta diabases}

Kiperjärvenoja

The mean composition of the dyke is quartz normative tholeiite (Table 3). Total chemical composition through the dyke shows variation (Appendix 1 and Fig. 8). Whether this is caused by a heterogenous magma or concentration of phenocrysts, is not clear.

The groundmass analyses performed on the microprobe show no clear variation at the contact one. However, the groundmass is so coarse-grained that microprobe analyses could only be carried out to about $10 \mathrm{~cm}$ from the contact.

Representative analyses of plagioclase phenocrysts are given in Table 6 . Their composition at the fine-grained contacts is very homogenous, $\mathrm{An}_{66-68}$. These crystals (about $0.1-0.3 \mathrm{~mm}$ wide) are strongly altered so that the determination of anorthite content in some cases was impossible. The large variation of rim chemistry $\mathrm{An}_{35-67}$ might be caused by the alteration.

The matrix plagioclase composition is $\mathrm{An}_{42-64}$ and some slight difference toward the centre of the dyke can be found. 


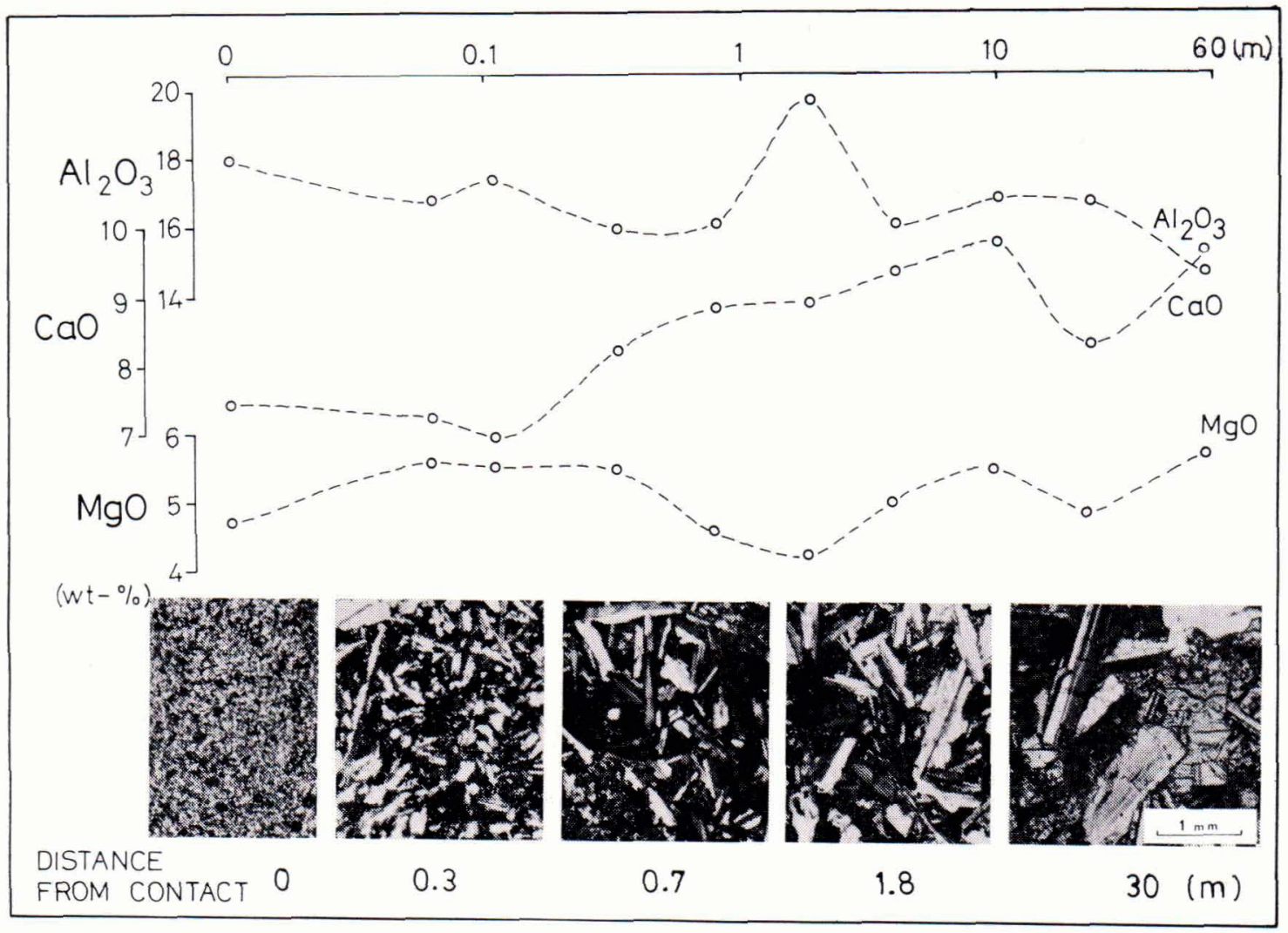

Fig. 8. $\mathrm{Al}_{2} \mathrm{O}_{3}, \mathrm{CaO}$ and $\mathrm{MgO}$ variation (total analyses) and the variation of the grain size of the dyke in Kiperjärvenoja, Satakunta. The numbers given below the photos refer to the distances from the contact. The scale is the same in all the photos.

Hinnerjoki I and II

The two sample suites represent the same dyke and show identical composition (Table 3).

The whole dyke is considerably altered. The groundmass through the whole dyke contains very small chlorite grains. The groundmass analyses performed by microprobe gave always the sum of about $94 \%$. The rest $(6 \%)$ is assumed to be volatiles.

However, to get the original magma composition, the chlorites were separated from the material and the powder was melted and further analysed by microprobe. However, the original groundmass analyses show that the chemistry through the dyke is very homogenous. Only slight $\mathrm{MgO}$ decrease toward the centre is observed, but this might be caused by smaller amounts of chlorites.

\section{Discussion}

Chemical compositions

Because of the different ages of the dyke sets it is unlikely that the magmas are derived from the same parental liquid. On the $\mathrm{MgO}-\mathrm{TiO}_{2}$ plot (Fig. 9) the different dyke sets plot separately. The Alland diabase set shows a variation trend towards $\mathrm{MgO}$-poorer magma, so that the Husö, Källsholm and Bergskär magmas can be derived from the Betesö magma fractionating $21-24 \%$ plagioclase and 15-17\% olivine. For Satakunta and Häme diabase sets relationships are more complicated. 


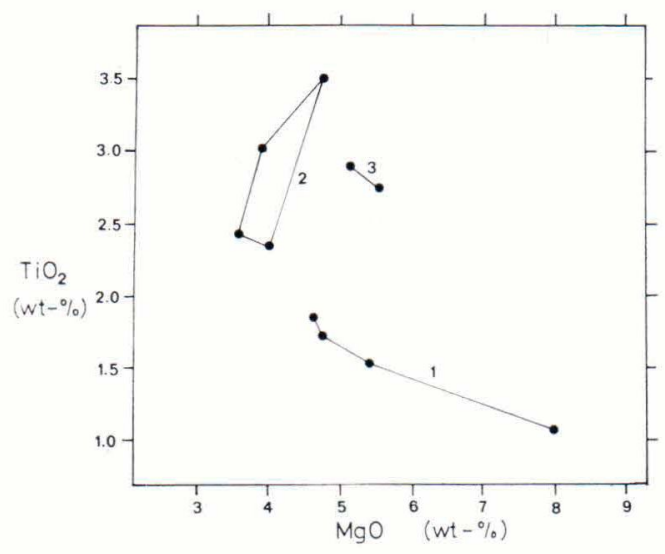

Fig. 9. $\mathrm{MgO}-\mathrm{TiO}_{2}$ variation diagram. 1) Alland set of diabase dykes. 2) Häme set of diabase dykes.

3) Satakunta set of diabase dykes.

To test possible genetic relationships the analyses were plotted on a $\mathrm{TiO}_{2}-\mathrm{P}_{2} \mathrm{O}_{5}$ diagram in Fig. 10. In addition to the data presented here some more primitive diabases from the same areas were also plotted. These few plotted analyses show that the studied diabases were not derived from the same magma by simple fractionation. All three different groups show reasonable trends. If the most primitive magma in Häme diabase set is similar to the Ansio magma (Table 3), then it follows that deriving most evolved magmas,
Orivesi III and Vehkajärvi, from the same source the differentiation conditions (pressure, temperature and $\mathrm{fO}_{2}$ ) must be different, otherwise the separate trends are difficult to explain. This can also be seen on the plagioclase phenocryst compositions. Vehkajärvi and Orivesi II both have plagioclase composition about $\mathrm{An}_{55}$, while Orivesi I and III have $\mathrm{An}_{62}$, which means that the crystallization conditions were different. Thus, from Ansio magma it is feasible to differentiate Orivesi I-Orivesi III and Orivesi II-Vehkajärvi in different ways.

The same holds for Satakunta diabases. We can not fractionate Kiperjärvi from Hinnerjoki, but both can be fractionated from a magma richer in $\mathrm{MgO}$ (Sorkka, Table 3). How to get such possible different parental liquids is discussed in the next chapter.

\section{Pressure-temperature relations}

The fact that most of the diabase dykes are geographically associated with the rapakivi intrusions does not necessarily mean that they are genetically and chemically related to the rapakivis, as widely has been argued. In some cases when the dikes are of the same age as rapakivi granite, the primary frac-

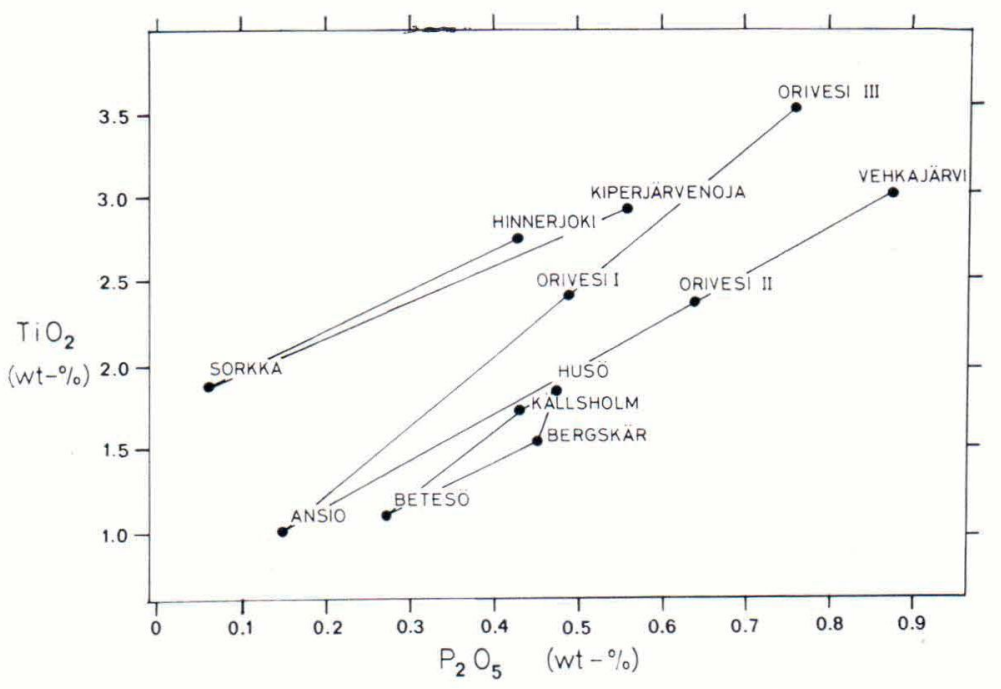

Fig. 10. $\mathrm{P}_{2} \mathrm{O}_{5}-\mathrm{TiO}_{2}$ variation diagram showing the possible genetical relationships between the studied diabase dykes. 
Table 7. Mixing calculations for deriving the Husö magma from partially melted garnet lherzolite.

\begin{tabular}{|c|c|c|c|c|c|c|c|c|c|}
\hline & Composition & $\mathrm{SiO}_{2}$ & $\mathrm{TiO}_{2}$ & $\mathrm{Al}_{2} \mathrm{O}_{3}$ & $\mathrm{FeO}$ & $\mathrm{MgO}$ & $\mathrm{CaO}$ & $\mathrm{Na}_{2} \mathrm{O}$ & $\mathrm{K}_{2} \mathrm{O}$ \\
\hline 1. & Garnet lherzolite & 44.5 & 0.3 & 2.8 & 10.2 & 37.9 & 3.3 & 0.3 & 0.1 \\
\hline 2. & $20 \%$ partial melting & 50.3 & 1.1 & 12.3 & 10.4 & 10.0 & 12.0 & 1.5 & 0.7 \\
\hline 3. & Betesö magma & 49.1 & 1.1 & 15.3 & 12.7 & 8.0 & 9.3 & 2.5 & 1.3 \\
\hline & $\begin{array}{l}72 \% \text { liquid } 3 .+5 \% \text { olivine }+ \\
23 \% \text { clinopyroxene }\end{array}$ & 50.2 & 1.0 & 12.2 & 10.8 & 10.0 & 12.2 & 1.8 & 0.9 \\
\hline 5. & Difference $2-4$ & 0.1 & 0.1 & 0.1 & 0.4 & 0.0 & 0.2 & 0.3 & 0.2 \\
\hline 6. & Husö magma & 53.9 & 1.9 & 15.3 & 12.4 & 4.6 & 8.1 & 2.3 & 1.0 \\
\hline 7. & $\begin{array}{l}57 \% \text { liquid } 6 .+19 \% \text { olivine }+ \\
24 \% \text { plagioclase }\end{array}$ & 49.1 & 1.1 & 15.5 & 12.6 & 8.0 & 9.1 & 2.1 & 0.7 \\
\hline & Difference $3-7$ & 0.0 & 0.0 & 0.2 & 0.1 & 0.0 & 0.2 & 0.4 & 0.6 \\
\hline
\end{tabular}

turing of the country rock is possibly due to the rising of rapakivi magma.

In a model constructed by Vorma (1977) the formation of rapakivi magma is due to the partial melting of the lower crust during the culmination of the svecofenno-karelian orogeny, about 1900-1800 Ma ago. During the first orogenic stages the basaltic magma from the mantle source possibly (discussed later) intruded and stored into the crust (Vorma, 1977).

At the subjotnian time, about $1700-1600$ Ma ago, large-scale block movements took place in Fennoscandia (see e.g. Vorma, 1977). During that episode the rapakivi magma rose into the higher levels of the crust, accompanied by volcanic eruptions. The deep fractures and faults formed at the time may have extended into the mantle and at this time the basaltic magma may have erupted and the present diabase dike sets were left in the former conduits.

The parental mantle material of basalts is assumed to be garnet peridotite, which is stable in the upper mantle conditions. According to Kushiro (1973) the partial melting of the garnet lherzolite under the mantle conditions $\left(1475^{\circ} \mathrm{C}, 20 \mathrm{~kb}\right)$ produces a liquid with composition given in Table 7 . This liquid represents about $20 \%$ melting of peridotite consisting mainly of pyroxenes and small amounts of olivine components.
The liquid is basaltic in character. Plagioclase can not be observed, because it is not stable at $20 \mathrm{~kb}$. In order that this liquid could yield the most primitive basalt here (Betesö, Aland set) from it must first fractionate ferro-magnesian minerals and the liquid must be separated from the crystals. If the magma arrived into the lower crust during the orogeny, its temperature and pressure decreased, resulting in marked pyroxene and olivine crystallization. The Betesö magma can be derived from the partially melted peridotite (Table 7 ) by separating about $23 \%$ clinopyroxene and $5 \%$ olivine. The difference between the actual and calculated composition is very small. The more primitive magmas of Ansio (Häme set) and Sorkka (Satakunta set) can be derived in a similar away.

This process may be followed on a An-DiFo diagram. Although this diagram is very simple, it can be used to demonstrate pressure and crystallization relationships, see e.g. Pressnall et al. (1978) and Mäkipää (1978b). The extreme members (Betesö-Husö) of the Åland diabase dykes are plotted in Fig. 11. In spite of the paradox that Kushiro's (1973) $20 \mathrm{~Kb}$ experimental melted lherzolite does not lie on the $20 \mathrm{~Kb}$ cotectic line, the diagram shows the principal direction of crystallization. Assuming the partially melted peridotite to be the parental liquid, clinopyroxene and olivine starts to fractionate at about 20 


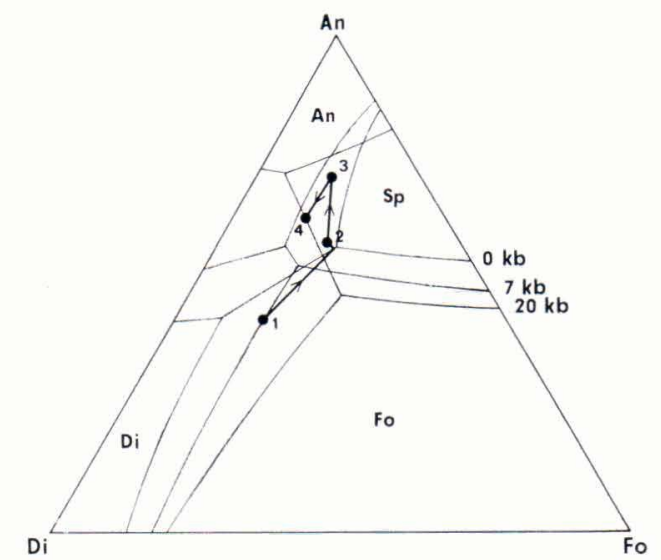

Fig. 11. The equilibrium diagram of the system Anorthite-Diopside-Forsterite. Different pressure lines drawn from Presnall et al. (1978). 1) Garnet lherzolite (Table 7). 2) Betesö magma (Table 3). Husö magma (Table 3). 4) Husö groundmass (Table 3).

$25 \mathrm{~kb}$ pressure. Separation and ascent into the lower crust would decrease the pressure and the composition of the magma lies within the spinel field. Because the spinel composition $\mathrm{MgAl}_{2} \mathrm{O}_{4}$ does not lie within the diagram, the fractional crystallization involving spinel cannot be described completely. However, the important feature is that the spinel reacts with the liquid, forming olivine and plagioclase. This part of evolution requires about $24 \%$ plagioclase and $19 \%$ olivine crystallization.

It should be noted that the tie lines in Fig. 11 are only to give the direction of crystallization on the basis of this diagram. During the ascent the pressure decreases and the composition of Husö magma now lies within the plagioclase field. Plagioclase is therefore the only mineral occurring as phenocrysts. As more plagioclase crystallize the composition of the liquid moves towards the cotecticum and finally eutecticum. This can be seen in the widest dykes where the crystallization is complete and the amount of olivine and pyroxene in the groundmass gradually increase towards the centre of the dyke.

The depth of the crystallization of the matrix cannot be determined accurately. The fact that the magmas at this level are not cotectic, means that all the pressures derived are too high. However, all analyses (except Satakunta diabases) plot around $2 \mathrm{~kb}$ line ( $\sim 6 \mathrm{~km}$ ), which gives the maximum pressure. According to this diagram the Aland diabases represent the deepest erosion level.

The temperature of the into the joints intruded magma can be estimated by the method described by Mäkipää (1979), and the results are tabulated in Table 8 . Because of the very slight crystallization next to the contact, the magma is assumed to be at very near the liquidus temperature at the time of intrusion. The intrusion temperature appears not to be the same in all the dykes of the same set. Again the Vehkajärvi-Orivesi II and Orivesi I-Orivesi III magmas separate by different liquidus temperatures (difference $\sim 25^{\circ}$ (C) as well as different plagioclase equilibrium temperatures. So do also the Kiperjärvenoja and Hinnerjoki dykes. This indicates either lack of equilibrium or different conditions during the earlier evolution of these magmas.

The fact that plagioclase is the only phenocryst mineral in most of the studied dykes, sets a limit to the calculation of the accurate equilibrium temperatures, because the equilibrium depends on the prevailing water pressure. It seems most likely that the water pressure was around $1 \mathrm{~kb}$ or less. The results (Table 8) using the Kudo \& Weill (1970) and Mathez (1973) plagioclase geothermometer show that the crystallization temperature of the matrix is about $50{ }^{\circ} \mathrm{C}$ lower than the liquidus. It is noticeable that the phenocryst equilibrium temperatures are similar to the groundmass temperatures. This indicates that the magma was wholly in a liquid form during the arrival into the lower crust, where the phenocryst crystallization took place.

For testing the feasibility of these tem- 
Table 8. Liquidus temperatures (calculated using the method described by Mäkipää 1979) and plagioclase equilibrium temperatures for megacryst-groundmass, phenocryst-groundmass and groundmass plagioclase-groundmass pairs.

mc-megacryst, pc-phenocryst, $\mathrm{mc}_{\max }$ or $\min$ and $\mathrm{pc}_{\max }$ or $\min$ refer to the calculated maximum and minimum temperatures, respectively, max or min refers to the groundmass plagioclase-groundmass maximum or minimum temperatures, respectively.

\begin{tabular}{|c|c|c|c|c|c|c|c|c|}
\hline & & & & & yioclase & quilibr & tempe & ture \\
\hline San & ple & Liq. T $\left({ }^{\circ} \mathrm{C}\right)$ & & do \& W & & & Mathez & \\
\hline & & & $0 \mathrm{~kb}$ & $1 \mathrm{~kb}$ & $2 \mathrm{~kb}$ & $0 \mathrm{~kb}$ & $1 \mathrm{~kb}$ & $2 \mathrm{~kb}$ \\
\hline Husö & $m c_{\max }$ & 1168 & 1172 & 1087 & 1010 & 1142 & 1114 & 1029 \\
\hline & $\mathrm{mc}_{\min }$ & & 1081 & 1001 & 916 & 1064 & 1009 & 924 \\
\hline & $\mathrm{pc}_{\max }$ & & 1173 & 1088 & 1003 & 1142 & 1115 & 1030 \\
\hline & $p c_{\min }$ & & 1157 & 1073 & 988 & 1129 & 1097 & 1012 \\
\hline & $\max$ & & 1175 & 1089 & 1004 & 1144 & 1117 & 1032 \\
\hline & $\min$ & & 1164 & 1080 & 995 & 1135 & 1105 & 1020 \\
\hline Bergskär & $\max$ & 1151 & 1173 & 1087 & 1002 & 1142 & 1114 & 1029 \\
\hline & $\min$ & & 1149 & 1064 & 979 & 1122 & 1087 & 1002 \\
\hline Betesö & $\max$ & 1250 & 1182 & 1101 & 1016 & 1152 & 1129 & 1044 \\
\hline & $\min$ & & 1114 & 1037 & 952 & 1093 & 1052 & 1067 \\
\hline Källsholm & $\max$ & 1159 & 1226 & 1141 & 1052 & 1189 & 1177 & 1097 \\
\hline & $\min$ & & 1188 & 1105 & 1020 & 1156 & 1134 & 1049 \\
\hline Vehkajärvi & $\operatorname{mc}_{\max }$ & 1139 & 1227 & 1140 & 1051 & 1189 & 1177 & 1097 \\
\hline & $\mathrm{mc}_{\min }$ & & 1158 & 1075 & 990 & 1130 & 1099 & 1014 \\
\hline & $\mathrm{pc}_{\max }$ & & 1238 & 1150 & 1065 & 1199 & 1189 & 1109 \\
\hline & $\mathrm{pc}_{\min }$ & & 1213 & 1126 & 1041 & 1177 & 1160 & 1080 \\
\hline & $\max$ & & 1228 & 1141 & 1052 & 1190 & 1178 & 1098 \\
\hline & $\min$ & & 1156 & 1073 & 988 & 1128 & 1096 & 1011 \\
\hline Orivesi I & $\max$ & 1161 & 1222 & 1137 & 1052 & 1186 & 1172 & 1092 \\
\hline & $\min$ & & 1214 & 1129 & 1044 & 1178 & 1163 & 1083 \\
\hline Orivesi II & $\max$ & 1147 & 1215 & 1129 & 1044 & 1179 & 1163 & 1083 \\
\hline & $\min$ & & 1206 & 1120 & 1035 & 1171 & 1153 & 1068 \\
\hline Orivesi III & $\max$ & 1173 & 1240 & 1153 & 1068 & 1201 & 1192 & 1112 \\
\hline & $\min$ & & 1226 & 1140 & 1051 & 1189 & 1176 & 1096 \\
\hline Kiperjärvenoja & $m c_{\max }$ & 1162 & 1267 & 1182 & 1106 & 1226 & 1224 & 1144 \\
\hline & $\mathrm{mc}_{\min }$ & & 1208 & 1126 & 1041 & 1174 & 1158 & 1073 \\
\hline & $\mathrm{pc}_{\max }$ & & 1265 & 1179 & 1099 & 1223 & 1221 & 1141 \\
\hline & $\mathrm{pc}_{\min }$ & & 1183 & 1103 & 1018 & 1153 & 1130 & 1045 \\
\hline & $\max$ & & 1270 & 1184 & 1104 & 1228 & 1227 & 1147 \\
\hline & $\min$ & & 1208 & 1126 & 1041 & 1175 & 1159 & 1074 \\
\hline Hinnerjoki & $\max -\min$ & 1169 & 1287 & 1201 & 1121 & 1243 & 1246 & 1166 \\
\hline
\end{tabular}

perature calculations, some crystallization experiments have been performed at the pressure of one atmosphere. The results sofar indicate that reasonable approximations can be achieved by the method described above.

\section{Phase-equilibria}

The only method available to test the plagioclase equilibrium is the major element distri- bution between plagioclase and liquid as a function of temperature.

Taking the plagioclase temperatures from Table 8 and supposing that they are equilibrium temperatures, all the microphenocrysts and the rim of the phenocrysts and megacrysts appear to be in a reasonable equilibrium (Fig. 12).

When attempting to clarify the mega- and phenocryst core equilibrium, the densities of 


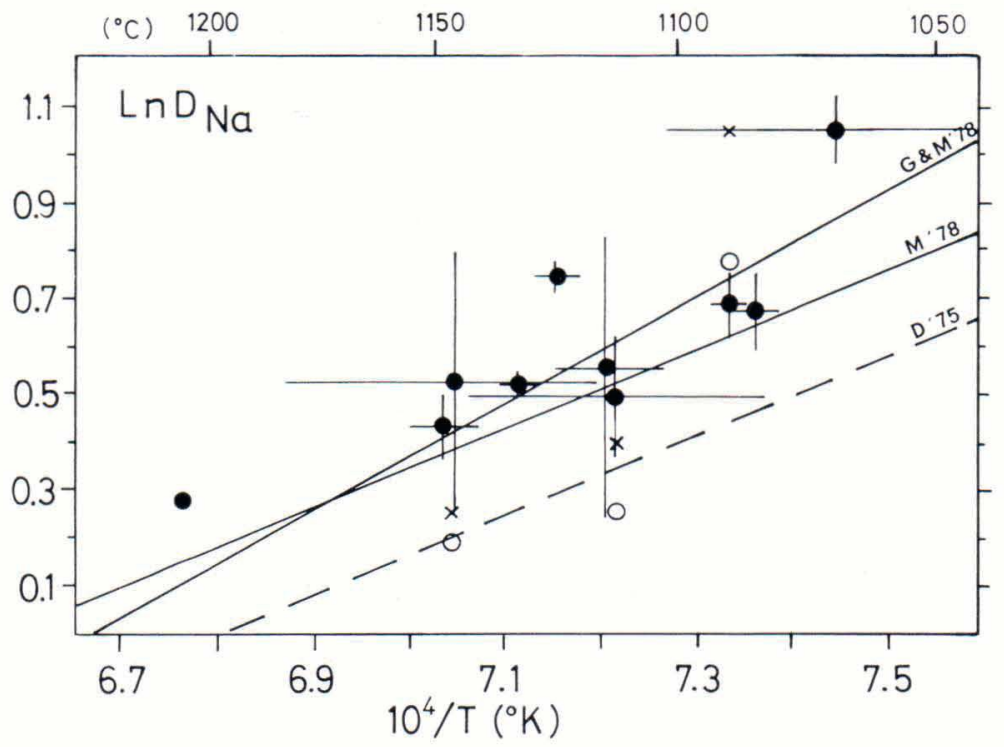

Fig. 12. Regression curve for $\ln D_{\mathrm{Na}}$ versus $1 / \mathrm{T}\left({ }^{\circ} \mathrm{K}\right)$, where $\mathrm{D}_{\mathrm{Na}}=$ (weight of $\mathrm{Na}$ in plagioclase)/(weight of $\mathrm{Na}$ in matrix) Solid circles refer to the groundmass, open circles to the phenocryst and crosses to the megacryst plagioclases (phenoand megacrysts only for Husö, Vehkajärvi and Kiperjärvenoja dykes). Dashed line (D'75) indicates equilibria in Drake's (1975) experiments. Solid lines are drawn from Mäkipää (1978) (M'78) and Grönvold \& Mäkipää (1978) (G \& M'78). Bars indicate the difference of maximum and minimum composition and temperatures. the crystals play a most important role. For example, in Husö dyke large megacrysts could have been formed at greater depths and floated in the magma chamber into the liquid, where they are now found. Considering higher pressures, these crystals are in equilibrium with the groundmass and therefore formed in a similar or the same magma.

The reverse situation holds in Vehkajärvi dyke, where the mega- and phenocrysts were heavier than the surrounding magma. These crystals were in equilibrium with the groundmass, if lower pressures were postulatel. However, according to the foregoing discussion about the crystallization history of these dykes, this model is an impossibility. Therefore the large megacrysts of the Vehkajärvi dyke cannot be crystallized from a magma corresponding the composition of the surrounding matrix.

\section{Cooling rate and crystallization history}

Cooling rates

The cooling rate of the magma in a dyke can be estimated using the results of experi- ments by Grove \& Walker (1977). They found that the size of plagioclase (width of the 010 pinacoid) correlates with the cooling rate as follows:

$\log ($ cooling rate $)=-1.71 \log ($ width $)-1.75$

The derived rates can be used to give some estimations of cooling rates. The results of different dykes on the same set are fully comparable.

The Aland diabase dyke show a linear cooling rate with distance from the contact (Fig. 13). Because the country rock is the same in all the dykes, the influence of the width of the dyke is distinct, the wider the dyke the lower the cooling rate, because of the greater heat capacity.

The Satakunta diabases show lowest cooling rates (Fig. 14), and the rate of cooling is almost constant up to about $10 \mathrm{~cm}$ from the contact. However, the temperature of the magma was so low that also contacts are completely crystallized even in the narrowest $(20 \mathrm{~cm})$ dykes. Further, the orientation of the groundmass plagioclases parallel to the dyke direction at contacts indicate that the magma was already partly crystallized before intrusion. 
Fig 13. Cooling rate curves of the dykes in Aland diabase set.

Fig. 14. Cooling rate curves of the dykes in Satakunta diabase set.
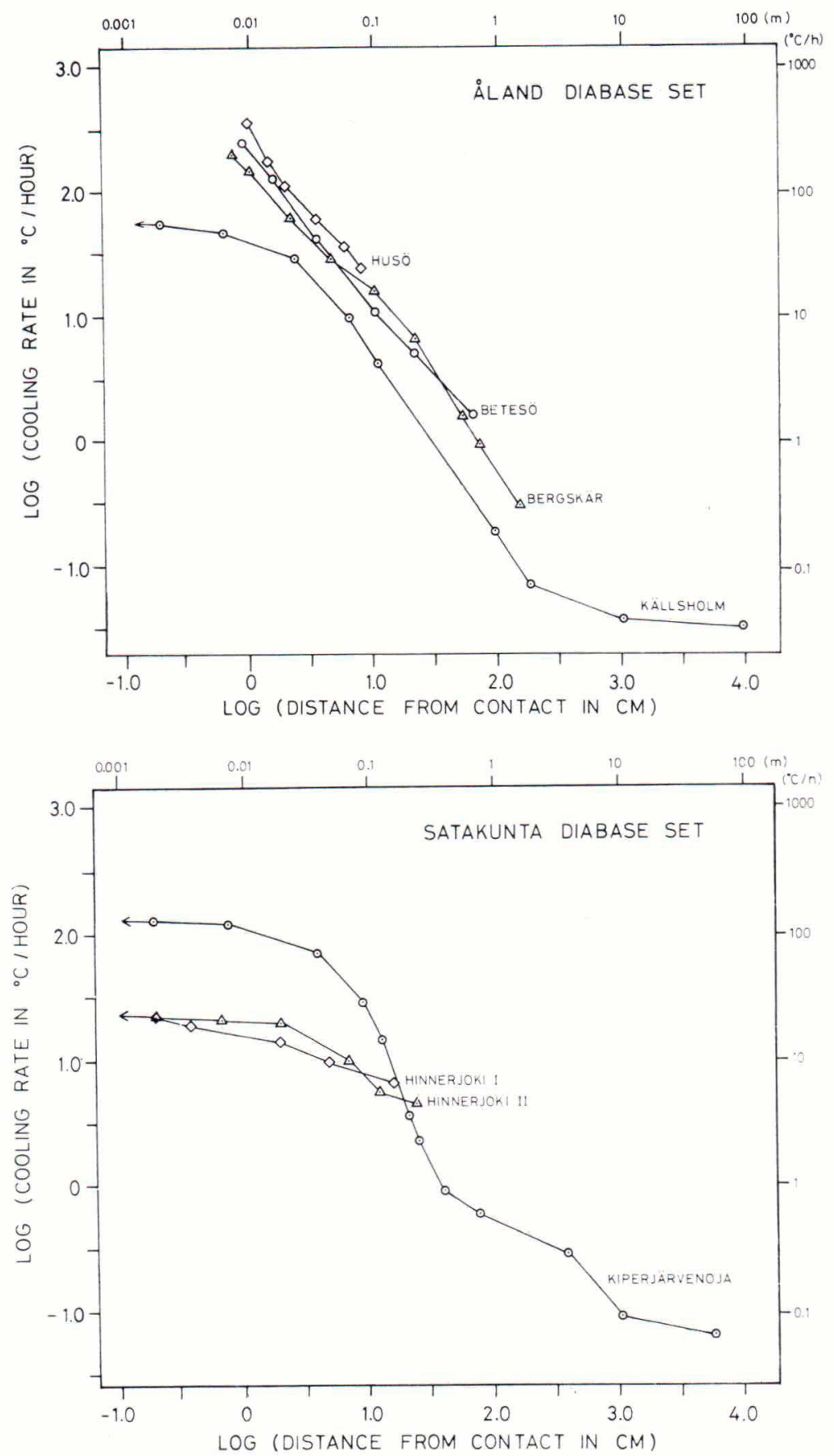

The Häme diabase set (Fig. 15) shows might be caused by relative high intrusion highest cooling rate at the contacts. However, the rates decrease rapidly and are lowest temperature. The Vehkajärvi dyke, having the lowest temperature, shows not so rapid cooling rate. Further the width of the 


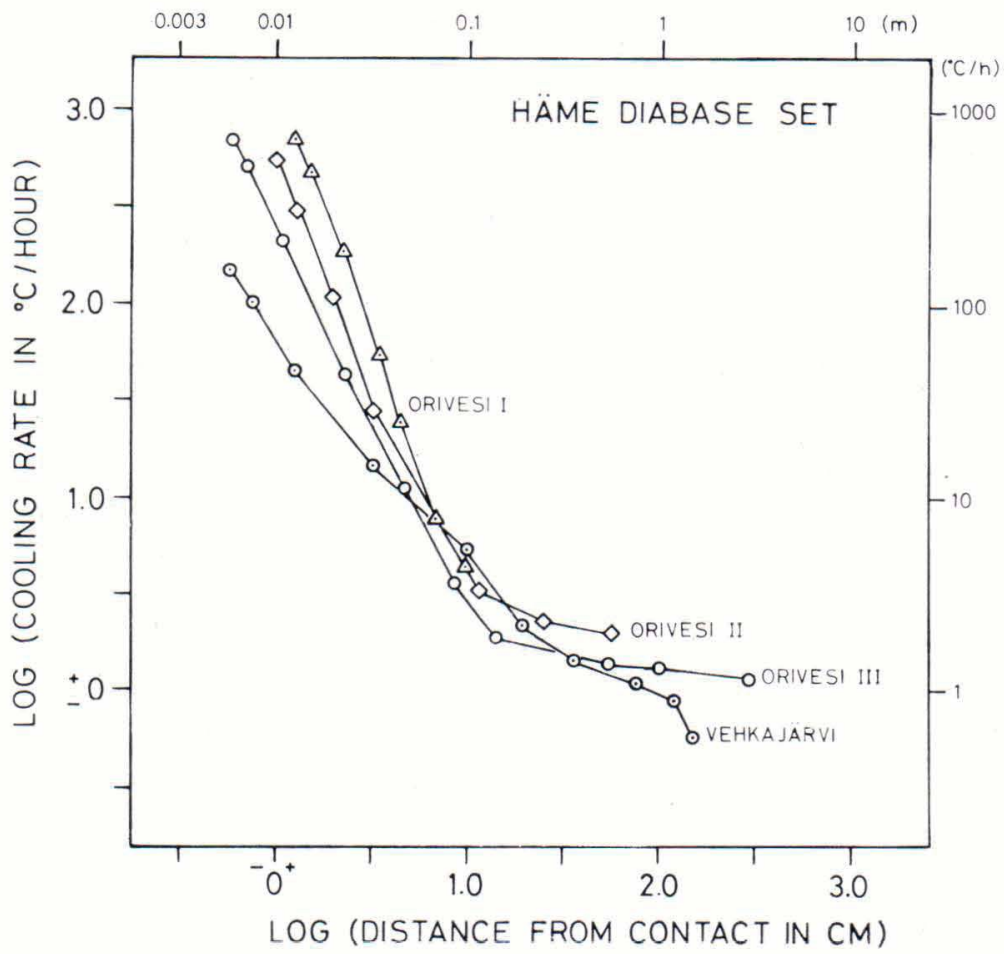

Fig. 15. Cooling rate curves of the dykes in Häme diabase set. chilled margins decrease with increasing width of the dyke.

All the present cooling rate experiments show similar behaviour as the results of Grove \& Walker (1977), i.e. the width of the plagioclase (010) pinacoid correlates lineary with the cooling rate, both in log scale (Fig. 16).

However, the slopes of the lines are very different. At higher cooling rates this can be caused by kinetic problems, but at lower rates there must be some other factor to control these individual experiments.

One important factor is the difference in the chemical composition. Grove \& Walker (1977) used quartz-normative lunar basalts with pyroxene and small amounts of olivine and spinel as the first crystallization phase. Plagioclase was the last phase to crystallize. At the early stage in their cooling rate experiments the number of pyroxenes increased and their size decreased as a func- tion of increasing cooling rate. They determined the pyroxene nucleation density and found it to correlate with the cooling rate. Then, during the late stages of crystallization the size of groundmass plagioclase increased at lower rate. So, applying this to the present experiments, the slope of the cooling rate line should be much steeper for early stage plagioclases than for late stage plagioclases. This is obvious. Does the line continue lineary at lower rates or turn parallel to late stage line is open to question.

However, another important result must also be pointed out. Three different dyke materials (Husö, Vehkajärvi and Kiperjärvenoja) were cooled simultaneously and the products reveal that the speed of the plagioclase growth differs in individual dykes, as shown in Fig. 16. This difference is small but noticeable. Applying this to Fig. 13 the discrepancy between the group Husö, Betesö 


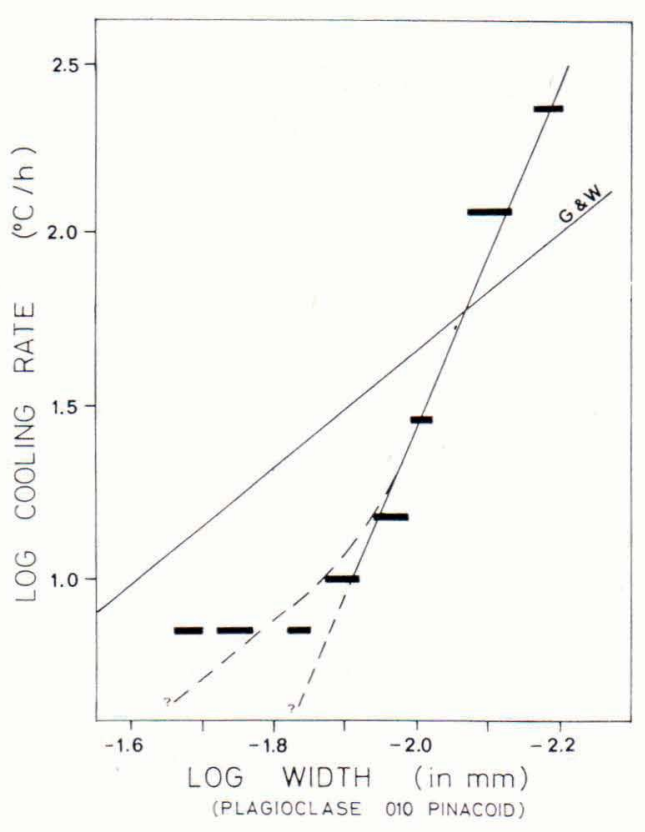

Fig. 16. Width of plagioclase phenocrysts measured in cooling rate experiments. Log of the width of plagioclase 010 pinacoid (in $\mathrm{mm}$ ) is plotted against the cooling rate. G \& W line represents late-stage cooling rates for lunar samples (Grove \& Walker, 1977).

and Bergskär dykes (amphibole diabases) and the Källsholm dyke (pyroxene diabase) is easy to understand. So the width of the dyke is not the only and primary factor to control the cooling rate, but also the chemical composition of the magma plays an important role.

\section{Contact phenomena}

The heat capacity of the Husö dyke during the cooling was small and the partially melted contact zone only extended a few millimeters into the country rock. When magma is intruded into a country rock containing hydrous minerals, heat will be absorbed by vaporizitation and the whole system will be surrounded by a zone rich in water vapor. Because water can intrude into the magma, the contacts contain more water

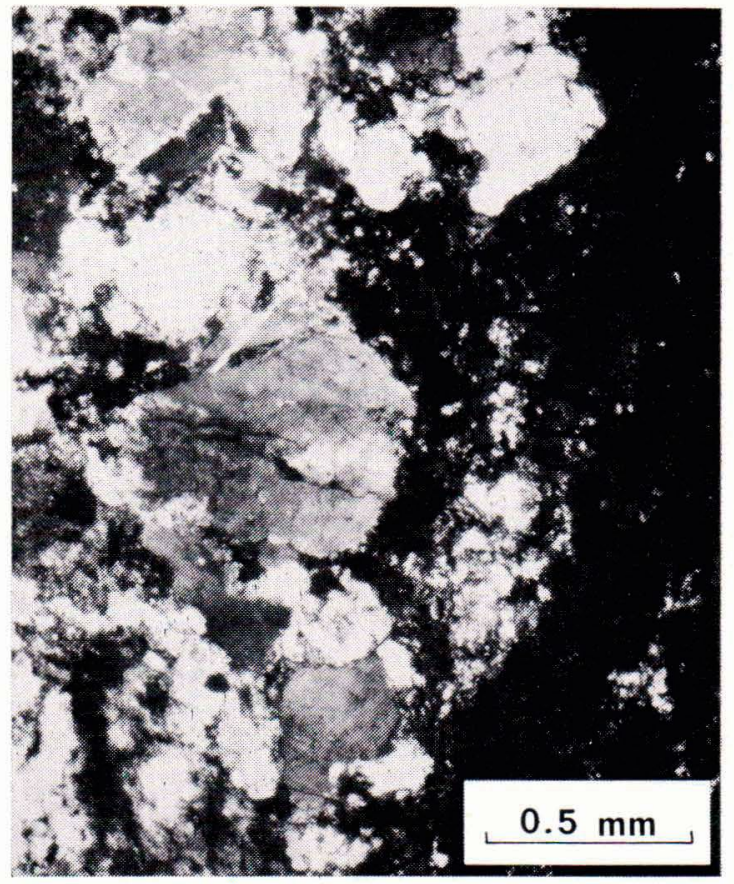

Fig. 17. A photomicrograph of the contact phenomena in Orivesi I diabase dyke. Note the partially melted country rock fragments in the dyke.

than the rest of the dyke. The formation of very small, fine-grained and colourless chlorites at the contacts of Husö dike at high temperature is probably due to the activity of hydrothermal solutions intruded into the magma from partially melted granodiorite. Another explanation is thermal metamorphism, but then also the crystallization of the glassy groundmass should occur, which is not evident.

Because of this water-vapor phenomenon also the saussurization of the plagioclase feldspars can be understood. In the zone extending about $4-5 \mathrm{~mm}$ from the contacts plagioclases are altered to epidote.

In the Vehkajärvi dyke the partial melting of the country rock was very slight, in spite of the fairly large heat capacity of the magma. At the contacts only $\mathrm{Na}_{2} \mathrm{O}, \mathrm{MgO}$ and FeO increase slightly, while $\mathrm{SiO}_{2}$ and $\mathrm{Al}_{2} \mathrm{O}_{3}$ 
decrease (Appendix 2). The altered zone is very narrow.

Extremely well the partial melting of the country rock occurs in some Orivesi dykes. The contact zones contain chlorites and even solution pubbles can be found (Fig. 17).

The contact zone is high in $\mathrm{K}_{2} \mathrm{O}, \mathrm{MgO}$ and $\mathrm{FeO}$ and low in $\mathrm{SiO}_{2}$ and $\mathrm{Na}_{2} \mathrm{O}$. The average total of many microprobe analyses is as low as about $90 \%$.

After the crystallization cooling joints opened in the dykes. They were immediately filled up by hydrothermal deposits with average composition $12 \% \mathrm{MgO}, 30 \% \mathrm{FeO}$, $13 \% \mathrm{Al}_{2} \mathrm{O}_{3}$ and $29 \% \mathrm{SiO}_{2}$. The rest $13-15 \%$ is probably water.

The Kiperjärvenoja dyke has contact with an arkosic sandstone. According to Kahma (1951) its contact influence is low grade. »Approaching the contact the quartz grains in sandstone become toothed and the amount of fine-grained cement decrease. This finegrained aggregate has almost entirely vanished at the contacts.»

The melted country rock material has flowed into the joint and mixed with contact magma. The mixing calculations show that about $35 \%$ of the fluidal material has mixed with the magma at contact zone, $\mathrm{MgO}$ and $\mathrm{FeO}$ increased, while $\mathrm{SiO}_{2}$ and $\mathrm{Al}_{2} \mathrm{O}_{3}$ decreased.

The present experiments show contact influence similar to those observed in the field. The partial melting of the country rock depends e.g. on the composition of dyke and country rock material, temperature, heating time and cooling rate. The degree of partial melting is directly comparable with the time used for preheating at high temperature $\left(1150-1200^{\circ} \mathrm{C}\right)$. The contact zone is always richer in $\mathrm{K}_{2} \mathrm{O}$ and $\mathrm{FeO}$, and poorer in $\mathrm{Na}_{2} \mathrm{O}$, $\mathrm{Al}_{2} \mathrm{O}_{3}$ and $\mathrm{SiO}_{2}$ than the rest of the dyke material in experimental capsule.

In one set of experiments powdered Husö

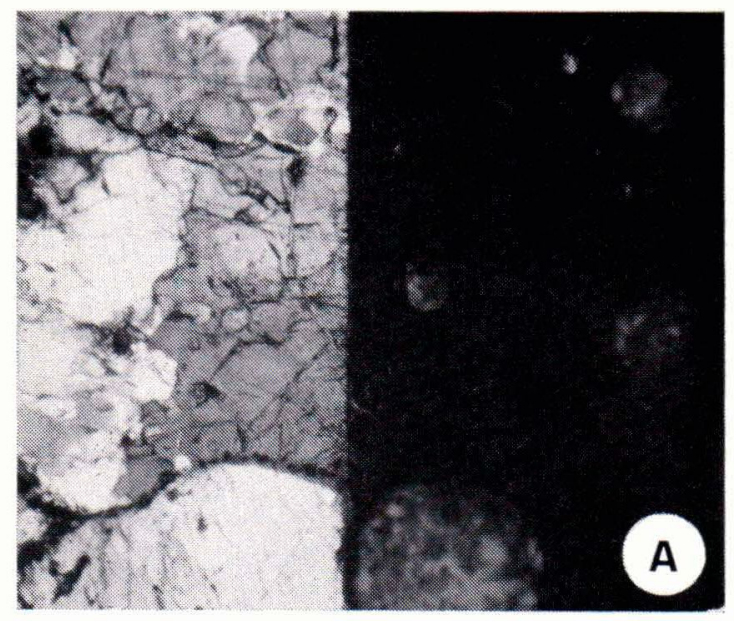

Fig. $18 \mathrm{~A}$. A photomicrograph of products resulting from the experimental run of Husö diabase and granodiorite (left) at $1160^{\circ} \mathrm{C}$ for one hour.

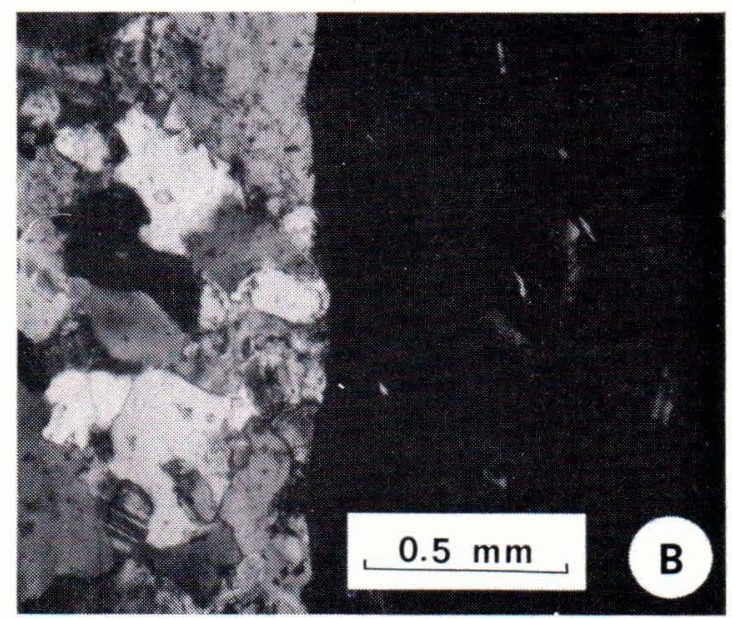

Fig. 18 B. A photomicrograph of Husö diabase granodiorite contact.

diabase and solid granodiorite were packed in a platinum capsule and suspended in a furnace at $1160^{\circ} \mathrm{C}$ for one hour and cooled afterwards using the rate of $180^{\circ} \mathrm{C} /$ hour. Figure 18A shows the basalt-granodiorite contact after the experimental procedure. $\mathrm{K}_{2} \mathrm{O}$ content of the diabase from the contact to the distance of about $1 \mathrm{~cm}$ decreases from $2.5 \%$ to $0.8 \%$, while e.g. $\mathrm{Al}_{2} \mathrm{O}_{3}$ increases from $13.3 \%$ to $15.3 \%$. This contact zone does 


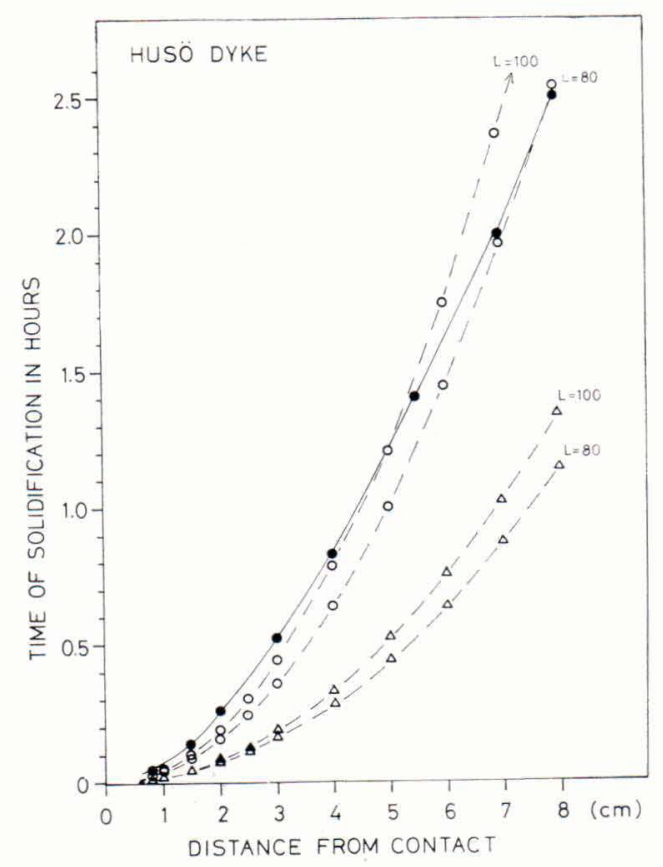

Fig 19. Time of the solidification as a function of the distance from contact in the Husö dyke. Solid circles - calculated using the experimental results of Grove \& Walker (1977). Open circles calculated using the method of Jaeger (1957) for intrusives. Triangles - calculated using the method of Jaeger (1957) for surface lava.

$\mathrm{L}=100$ - latent heat $100 \mathrm{cal} / \mathrm{g}$.

$\mathrm{L}=80-$ latent heat $80 \mathrm{cal} / \mathrm{g}$.

not extend more than a few millimeters to the diabase.

For comparison the natural contact of Husö dike is shown in Fig. $18 \mathrm{~B}$.

Duration of the solidification

Jaeger (1957) studied the cooling rates of igneous rocks and introduced a method to calculate the time needed by a magma at a surface of known distance from the contact to solidify completely.

As discussed earlier the contact zone absorbed heat effectively and the corresponding heat loss must be accounted for in the calculation. In the Husö dyke the time for solidification is calculated using $1170^{\circ} \mathrm{C}$ as liquidus and intrusion temperature (derived using the method by Mäkipää 1979) and $1120^{\circ} \mathrm{C}$ as solidus temperature (calculated plagioclase groundmass equilibrium temperature, Table $6)$. These temperatures agree well with the experimental results by Yoder \& Tilley (1962). They found that rocks similar to those studied here are completely crystallized after the cooling of $40-60^{\circ} \mathrm{C}$ from the liquidus.

In an attempt to account for the heat loss due to vaporization at the contacts, the temperature was assumed to be $30^{\circ} \mathrm{C}$ lower than the liquidus. The density of the magma was calculated using $1-2 \mathrm{~kb}$ pressure and $0.5 \%$ $\mathrm{H}_{2} \mathrm{O}$ content, which was assumed to be constant up to the contact zone where it was assumed to increase linearly up to $1.5 \%$ $\mathrm{H}_{2} \mathrm{O}$.

The results (Fig. 19) with different latent heats 80 and $100 \mathrm{cal} / \mathrm{g}$ are compared with the results of the method by Grove \& Walker (1977) and the cooling rates of the surface of a lava flow.

The agreement between the theoretical and experimental methods is good, and results may now be used quantitatively. According to these the solidification of Husö dyke was complete in $2-3$ hours after the intrusion.

The case of the Vehkajärvi dyke is more complicated because of the differentiation in the dyke. The time of solidification was calculated using $1140^{\circ} \mathrm{C}$ as the liquidus temperature and $1090^{\circ} \mathrm{C}$ as the solidus temperature. Assuming similar conditions as quoted above, the cooling curves are shown in Fig. 20, which indicates slower cooling rate at the contact than calculated. This is caused by the graywacke schist country rock, which does not absorb heat well, and further, the chilled contacts were continuously in contact with the hotter magma intruded into the joint. When the contact zone (about $1 \mathrm{~cm}$ ) is crossed, the cooling rate follows the calculated rate until it rapidly increases at the megacryst zone. Because of the very extensive crystallization the cooling rate is here 


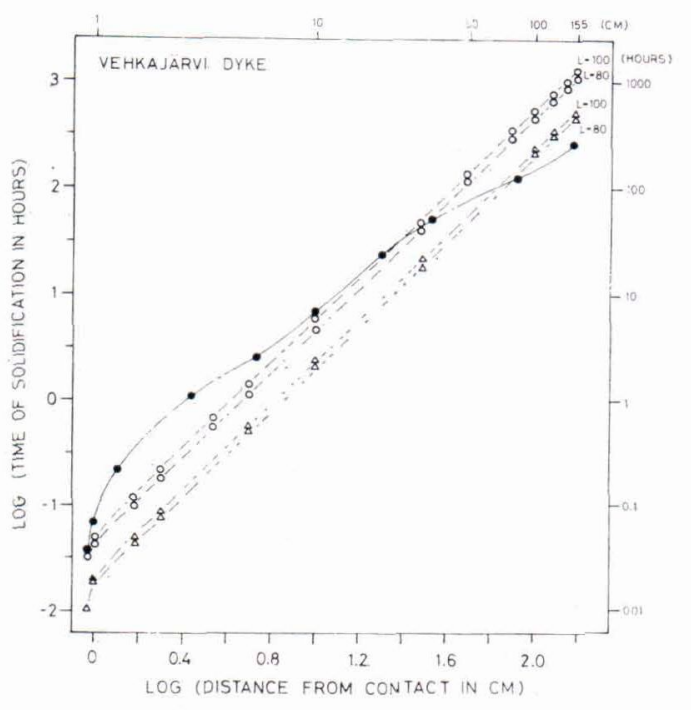

Fig. 20. Time of the solidification as a function of the distance from contact in the Vehkajärvi dyke. Symbols as in Fig. 20.

greater than calculated. However, according to the experimental results presented here, the cooling rate at the contact is not so rapid as calculated using the method of Grove \& Walker (1977), and in addition, the megacryst zone shows slower cooling rate, so that the agreement between Jaeger's and this study is even better than presented.

According to these results, the solidification of the Vehkajärvi dyke was complete in $40-50$ days after the intrusion. However, it seems to be more realistic to use the observed rate on the basis of plagioclase widths, which gives the result of two weeks.

The Kiperjärvenoja dyke is even more problematic, because of the differentiation and convection in the dyke during solidification. The time for solidification was calculated using $1170^{\circ} \mathrm{C}$ as intrusion temperature and $1120^{\circ} \mathrm{C}$ as solidus temperature. The comparison (Fig. 21) with the time derived from plagioclase widths shows marked difference. This is caused by at least three factors. Firstly, the effect of convention may play an important role. It seems certain that after the marginal phase solidification the heat convection was increasingly dominating factor.

The author has made some experimental calculation to establish the effect of convection on the contact temperature and on the duration of solidification. In these the temperature at Kiperjärvenoja contacts has risen by an amount of tens of degrees from the initial contact temperature. Considering a very effective heat circulation, the duration of solidification decreases to half of the calculated value.

Secondly, the method to calculate the time of solidification using the plagioclase widths requires the assumption that the growth of the crystals is continuous and linear. In the studied dykes the width of the plagioclase crystals increase linearly only in dykes narrower than about 20 meters. For example the width of the plagioclase crystals in the $60 \mathrm{~m}$ wide Kiperjärvenoja diabase and $100 \mathrm{~m}$ wide Källsholm dyke seems to be constant (about $0.6 \mathrm{~cm}$ ) from $25-30 \mathrm{~m}$ from the contact on.

Thirdly, according to the present early stage plagioclase cooling rate experiments, the agreement with the calculated rates is much better than presented but at lower rates it is now impossible to say if the growth continues linearly or not.

However, it seems unquestionable that the solidification time of Kiperjärvenoja dyke is in the order of a hundred years.

Settling of the plagioclase crystals

Using the Stokes' law it is possible to calculate the velocity required for a crystal rise or sink.

$$
\mathrm{V}=\frac{2 \mathrm{~g} \mathrm{a}^{2}\left(\mathrm{P}_{1}-\mathrm{P}_{2}\right)}{9 \mu}
$$

where $\mathrm{g}$ is acceleration due to gravity $\left(\sim 10^{3}\right.$ $\mathrm{cm} / \mathrm{sec}^{2}$ ), $\mathrm{a}=$ radius of the crystal, $\mathrm{P}_{1}=$ density of the crystal, $\mathrm{P}_{2}=$ density of the melt, 
Fig. 21. Time of the solidification as a function of the distance from contact in the Kiperjärvenoja dyke. Symbols as in Fig. 20.

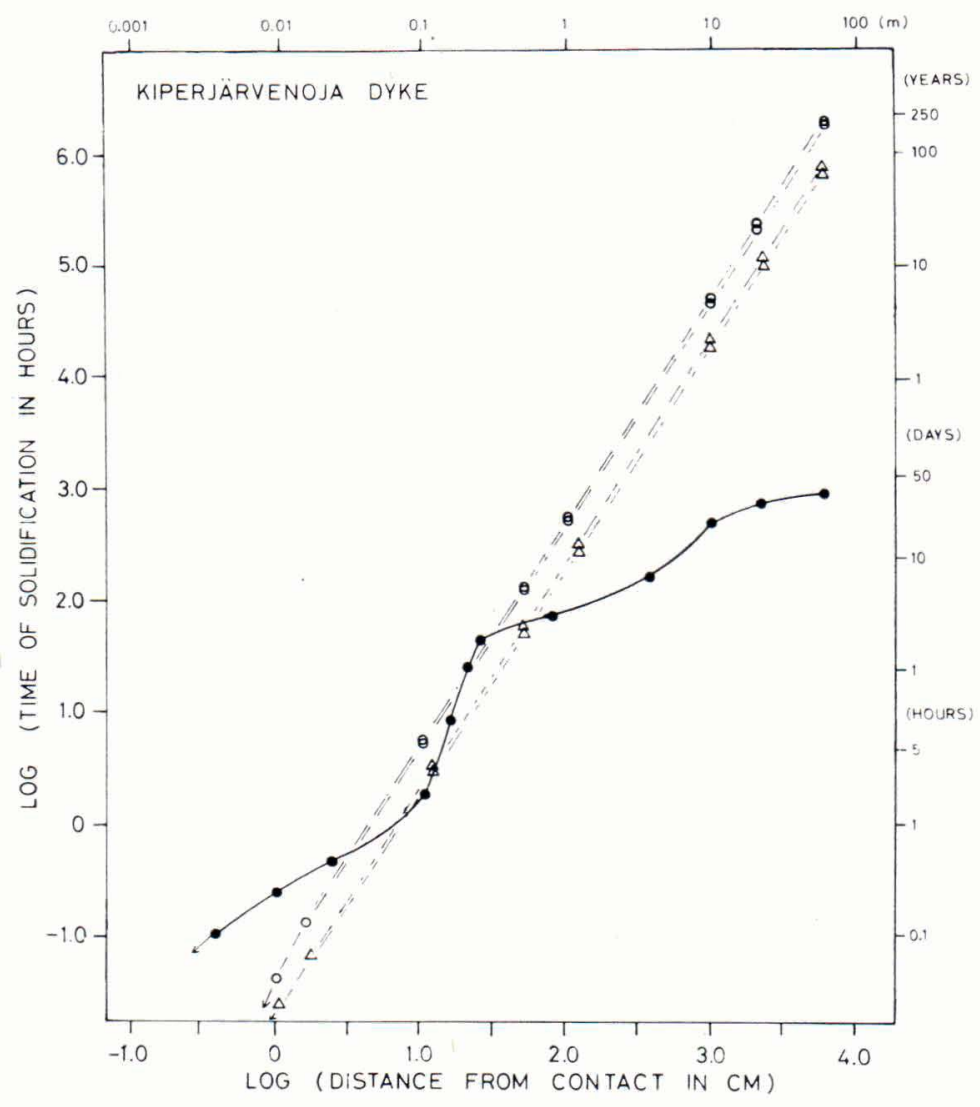

and $\mu=$ viscosity of the melt (calculated using the method of Shaw (1972)).

According to Bottinga \& Weill (1970) the total range of the density of plagioclase at $1200^{\circ} \mathrm{C}$ is 2.53 to 2.71 (corresponding to $\mathrm{An}_{0}-$ $\left.A n_{100}\right)$. The calculated densities are given in the tables with plagioclase analyses of individual diabase sets.

The density of a magma can be calculated from partial molar volumes of oxide components (Bottinga \& Weill, 1970).

Thus the density of the Husö plagioclase phenocrysts ( $\AA$ land diabase set) varies from $2.615-2.625\left(\mathrm{An}_{48-54}\right)$. The density of the larger megacrysts can be considered to be between 2.600 and $2.625\left(\mathrm{An}_{38-53}\right)$. Assuming the pressure of $1-2 \mathrm{~kb}$ and water content of $0.5 \%$, the specific gravity of the Husö groundmass at $1175^{\circ} \mathrm{C}$ is about 2.615. Considering the effective viscosity of the Husö magma to be about 1100 poises and the maximum radius of phenocrysts $0.2 \mathrm{~mm}$ the crystals should sink at the rate of $0.35 \mathrm{~mm} /$ day. This means that if the dyke is like a sill it takes half a year to remove the phenocrysts from the contact to the centre of the dyke. As discussed earlier the solidification of such a narrow dyke takes only hours.

Megacrysts can either sink or rise. Considering very common plagioclase megacryst composition $\left(\mathrm{An}_{40}\right)$ the crystals (max. $0.6 \mathrm{~cm}$ in diameter) should float at the rate of 0.8 $\mathrm{cm} / \mathrm{h}$.

On account of these velocities, the gravitative settling of plagioclases in Husö dyke is not a strong factor to move the crystals. The 
concentration of the mega- and phenocrysts into the centre of the dyke must be understood to be due to the flowage differentiation.

Vehkajärvi plagioclase phenocrysts (Häme diabase set) show slight variation in composition toward the centre of the dyke. However, as an average their density varies from 2.625 to $2.635\left(\mathrm{An}_{53-60}\right)$. The density of the extremely homogenous, large megacrysts $(\varnothing 2-3 \mathrm{~cm}$ ) varies from 2.630 to $2.635\left(\mathrm{An}_{55-59}\right)$.

The density of the Vehkajärvi groundmass is 2.59 at $1139^{\circ} \mathrm{C}$ (other properties quoted above).

Vehkajärvi magma has a viscosity of about 1200 poises at $1140^{\circ} \mathrm{C}$. The maximum radius of the phenocrysts is $0.1 \mathrm{~mm}$, denoting sinking at the rate of $0.7 \mathrm{~mm} /$ day. The large megacrysts can move in the magma at the rate of $1.7 \mathrm{~m} / \mathrm{h}$ and in this spirit the concentration of the plagioclase megacrysts in the middle of the dyke must be explained.

The first idea to rise is a simple model of magmatic chambers. Being much heavier than the magma, the megacrysts may have sunk to the bottom levels of the chamber. After the eruption the present megacryst zone may represent the last phase of the extracted material. However, this model should require a differentiation trend toward the centre of the dyke, which evidently does not occur. Further, the conditions during the eruption should be so ideal that the existence of this system is unlikely, and finally, as discussed earlier, the megacrysts are in equilibrium only if lower pressures are postulated.

Rather more probable is the existence of some mechanical sorting during the eruption. The only explanation worthy of consideration is the flowage differentiation. In such case the whole system is very stabil because of the higher viscosity of the concentration zone. This indicates that the less viscous magma on the both sides of the megacryst zone has flowed faster than the crystal-saturated liquid in the mid-channel. On this basis the chemical difference between the matrix in the central part of the dyke and other parts is easy to understand.

Anyway in both cases the dyke must represent a more or less vertical joint or otherwise some gravitative settling should cocur.

Kiperjärvenoja plagioclase phenocrysts (Satakunta diabase set) are homogenous and strongly altered. Their density varies between 2.645 and $2.650\left(\mathrm{An}_{66-68}\right)$. The density of the Kiperjärvenoja groundmass is 2.605 at $1165^{\circ} \mathrm{C}$ (other properties quoted above).

Kiperjärvenoja magma had a viscosity of 1150 poises at $1165^{\circ} \mathrm{C}$. The maximum radius of the phenocrysts observed near the contacts is $0.2 \mathrm{~mm}$, denoting sinking at the rate of about $3 \mathrm{~mm} /$ day.

Owing to the scaricity of the megacrysts such concentrations of the crystals as described in the Vehkajärvi dyke cannot be found. Because the distinction between the phenocrysts and groundmass minerals behind the contact zones is impossible under the microscope, the total analyses are the only facts relating possible crystal concentration during the intrusion.

\section{Summary}

The crystallization history of ten dykes from three different diabase sets in southern Finland has been described. The basaltic magma was formed by partial melting of the upper mantle during the Svecofenno-Karelian folding, and it intruded into the crust during this folding.

The intrusion temperature has been derived to be about $1140-1170^{\circ} \mathrm{C}$ and no clear distinction between individual sets can be made. The calculated equilibrium temperatures show that the dykes in most cases were 
completely crystallized after a cooling of $40-60^{\circ} \mathrm{C}$.

The magma at this temperature has par tially melted the country rock. In the narrowest dykes the melted zone extends only a few millimeters into the country rock, but in the largest ones the zone is several tens of centimetres. The melting has also influenced the diabase chemistry up to $3-4$ meters from the contact, as has been described by Kahma (1951). Also some differentiation in the dyke self occurs in the widest dykes.

The lack of any variation in the groundmass chemistry around the mega- and phenocrysts indicates that they already were in the magma before intrusion. The homogenity of the mega- and phenocrysts can be explained by magma chambers, which evidently existed for a long time beneath the diabase areas.

The cooling rate of the magma depends on the country rock, dyke chemistry, intrusion temperature and the width of the dyke. To generalize, the width of the chilled margins is the function of the width of the dyke. Further, the larger the dyke the slower is the cooling rate, and the higher the intrusion temperature the speedier is the cooling rate at the contacts.

\section{References}

Bottinga, Y. and Weill, F. (1970) Densities of liquid silicate systems calculated from partial molar volumes of oxide components. Am. J. Sci. 269: 169-183.

Drake, M. J. (1975) Plagioclase thermometry and barometry in igneous systems. In Extended abstracts: International Conference on Geothermometry and Geobarometry, Pennsylvania State University, Pennsylvania.

Ehlers, C. and Ehlers, M. (1977) Shearing and multiple intrusion in the diabases of Aland
The settling of the plagioclase mega- and phenocrysts in the centre of the dykes is explained here by a process of flowage differentiation. However, in most of the dykes in the studied areas the plagioclase crystals occur near the assumed upper or lower contact. Very popular explanation to this phenomenon is the gravitative differentiation in the dyke itself. However, this study shows that such conclusions must be made with great care.

Considering the plagioclase cell expansion at high temperature and the magma density variation with temperature and pressure, the density of the plagioclases in most dykes equals the density of the magma. In the narrowest dykes there has not been time enough to the gravitative separation of the crystals and therefore the origin of the crystal-concentration in one part of the dyke must be in magma chamber at a shallow depth or even deeper.

Acknowledgements - This study was carried out during the author's fellowship at the Nordic Volcanological Institute, Reykjavik. The author is indebted to Dr. Ilkka Laitakari and Mr. Veli Suominen, Phil.lic., for their advice, help and hospitality during the field trip in Finland. Thanks are also due to them and Dr. Gudmundur Sigvaldason for valuable discussion during the work. Drs. Karl Grönvold and Atso Vorma kindly read the manuscript and made a number of suggestions; this is gratefully acknowledged.

archipelago, SW Finland. Geol. Surv. Finland, Bull. 289, $31 \mathrm{p}$.

Grove, T. L. and Walker, D. (1977) Cooling histories of Apollo 15 quartz normative basalts. Proc. Lunar Sci. Conf. 8th: 1501-1520.

Grönvold K. and Mäkipää, H. (1978) Chemical composition of Krafla lavas 1975-1977. Rapport Nordic Volcanological Institute 78-16.

Haapala, I. (1977) Petrography and geochemistry of the Eurajoki stock, a rapakivi-granite complex with greisen-type mineralization in south- 
western Finland. Geol. Surv. Finland, Bull. 286, $128 \mathrm{p}$.

Irvine, T. N. and Baragar, W. R. A. (1971) A guide to the chemical classification of the common volcanic rocks. Can. J. Earth Sci. 8: 523-549.

Jaeger, J. C. (1957) The temperature in the neighbourhood of a cooling intrusive sheet. Am. J. Sci. 255: $306-318$.

Kahma, A. (1951) On contact phenomena of the Satakunta diabase. Bull. Comm. géol. Finlande 152. $84 \mathrm{p}$.

Kudo, A. M. and Weill, D. F. (1970) An igneous plagioclase geothermometer. Contr. Mineral. Petrol. 25: 52-65.

Kushiro, I. (1973) Partial melting of garnet lherzolites from kimberlite at high pressures. In: P. H. Nixon (ed.) Lesotho kimberlites, Lesotho National Development Corporation, Maseru, Lesotho, 294-299.

Laitakari, A. (1925) Über das Jotnische Gebiet von Satakunta. Bull. Comm. géol. Finlande 73. 43 p.

- (1928) Palingenese am Kontakt des postjotnischen Olivindiabases. Fennia 50 (35). 25 p.

Laitakari, I. (1966) Heinolan-Padasjoen-Oriveden seudun diabaasijuoniparvi. Thesis, Geological Institute, University of Turku. $157 \mathrm{p}$.

- (1969) On the set of olivine diabase dikes in Häme, Finland. Bull. Comm. géol. Finlande 241. $65 \mathrm{p}$.

Lokka, L. (1934) Neuere Chemische Analysen von Finnischen Gesteinen. Bull. Comm. géol. Finlande 105. $64 \mathrm{p}$.

Mäkipää, H. T. (1978 a) Petrological relations in some Icelandic basaltic hyaloclastites. Bull. Geol. Soc. Finland 50: 81-112.

- (1978 b) Mineral equilibria, geothermometers and geobarometers in some Icelandic hyaloclastites. Bull. Geol. Soc. Finland 50: 113-134.

- (1979) Contribution to the $\mathrm{Fe}_{2} \mathrm{O}_{3} / \mathrm{FeO}$ determination in basaltic rocks. Bull. Geol. Soc. Finland 51: $125-129$.

Mathez, E. A. (1973) Refinement of the Kudo-Weill plagioclase thermometer and its application to basaltic rocks. Contr. Mineral. Petrol. 41: 61 -72 .

Presnall, D. C., Dixon, S. A., Dixon, J. R., O'Donnell, T. H., Brenner, N. L., Schrock, R. L. and Dycus, D. W. (1978) Liquidus phase relations on the join Diopside-Forsterite-Anorthite from $1 \mathrm{~atm}$ to $20 \mathrm{kbar}$ : Their bearing on the generation and crystallization of basaltic magma. Contr. Mineral. Petrol. 66: 203-220.

Savolahti, A. (1956) The Ahvenisto massif in Finland. Bull. Comm. géol. Finlande 174. 96 p.

- (1964) Olivine diabase dike of Ansio in Padasjoki, Finland. Bull. Comm. géol. Finlande 215.

Sederholm, J. J. (1911) Beskrifning till bergartskartan B 2, Tammerfors. Résumé en francais. (General geological map of Finland) 1:400.000. 121 p.

- (1934) On migmatites and associated precambrian rocks of southwestern Finland. Part III. The Åland islands. Bull. Comm. géol. Finlande 107.

Shaw, H. R. (1972) Viscosities of magmatic silicate liquids: an empirical method of prediction. Am. J. Sci. 272: 870-893.

Vaasjoki, M. (1978) Rapakivi granites and other postorogenic rocks in Finland: their age and the lead isotopic composition of certain associated galena mineralizations. Geol. Surv. Finland, Bull. 294.

Vorma, A. (1977) On the petrochemistry of rapakivi granites with special reference to the Laitila massif southwestern Finland. Geol. Survey of Finland, Bull. 285.

Weigand, P. W. and Ragland, P. C. (1970) Geochemistry of Mesozoic dolerite dykes from eastern North America. Contr. Mineral. Petrol. 29: $195-214$.

Yoder, H. S. Jr. (1973) Contemporaneous basaltic and rhyolitic magmas. Am. Min. 58: 153-171.

- and Tilley, C. E. (1962) Origin of basalt magmas. J. Petrol. 3: 346-532.

Manuscript received, July 2, 1979 


\section{APPENDIX 1}

Total chemistry of the studied dykes.

\begin{tabular}{|c|c|c|c|c|c|c|c|c|c|c|c|}
\hline $\begin{array}{l}\text { Dist. from } \\
\text { cont. (cm) }\end{array}$ & $\mathrm{SiO}_{2}$ & $\mathrm{TiO}_{2}$ & $\mathrm{Al}_{2} \mathrm{O}_{3}$ & $\mathrm{FeO}^{\mathrm{t}}$ & $\mathrm{MnO}$ & $\mathrm{MgO}$ & $\mathrm{CaO}$ & $\mathrm{Na}_{2} \mathrm{O}$ & $\mathrm{K}_{2} \mathrm{O}$ & $\mathrm{P}_{2} \mathrm{O}_{5}$ & Total \\
\hline \multicolumn{12}{|l|}{ Husö dyke } \\
\hline 0 & 53.46 & 1.68 & 14.82 & 11.87 & .17 & 4.73 & 8.09 & 2.35 & 1.50 & .38 & 99.05 \\
\hline 1 & 53.92 & 1.47 & 15.23 & 11.84 & .18 & 4.60 & 8.44 & 2.24 & 1.11 & .33 & 99.36 \\
\hline 4 & 53.59 & 1.77 & 15.25 & 11.89 & .21 & 4.79 & 8.36 & 2.24 & 1.04 & .44 & 99.58 \\
\hline 6 & 52.94 & 1.78 & 15.56 & 11.62 & .14 & 4.96 & 8.51 & 2.28 & 1.22 & .45 & 99.78 \\
\hline Centre & 53.27 & 1.40 & 17.41 & 10.21 & .14 & 3.74 & 9.56 & 2.59 & 1.22 & .40 & 99.94 \\
\hline 7.5 & 53.43 & 1.39 & 17.25 & 10.40 & .14 & 3.75 & 9.30 & 2.61 & 1.20 & .36 & 99.82 \\
\hline 6 & 53.28 & 1.71 & 15.35 & 12.49 & .13 & 4.55 & 8.51 & 2.28 & 1.01 & .39 & 99.70 \\
\hline 3 & 53.08 & 1.78 & 14.73 & 12.69 & .13 & 5.00 & 8.59 & 2.31 & .85 & .37 & 99.53 \\
\hline 1 & 53.79 & 1.77 & 15.30 & 11.21 & .16 & 5.13 & 8.93 & 2.55 & 1.04 & .42 & 100.30 \\
\hline \multicolumn{12}{|c|}{ Vehkajärvi dyke } \\
\hline 0 & 50.98 & 3.33 & 15.04 & 13.47 & .17 & 3.95 & 6.84 & 2.67 & 2.27 & .82 & 99.54 \\
\hline 20 & 51.34 & 2.93 & 13.96 & 14.79 & .16 & 3.77 & 6.68 & 2.40 & 2.30 & .79 & 99.12 \\
\hline 50 & 51.91 & 2.77 & 15.14 & 12.60 & .16 & 3.92 & 7.03 & 2.65 & 2.12 & 1.03 & 99.33 \\
\hline 110 & 51.48 & 2.75 & 15.26 & 13.10 & .17 & 3.95 & 7.10 & 2.69 & 2.22 & .98 & 99.70 \\
\hline 125 & 50.37 & 3.48 & 16.88 & 11.82 & .14 & 3.60 & 7.68 & 2.79 & 1.96 & .73 & 99.45 \\
\hline Centre & 50.80 & 2.60 & 19.02 & 10.69 & .13 & 2.83 & 8.55 & 3.06 & 1.69 & .57 & 99.94 \\
\hline 110 & 50.98 & 2.81 & 15.38 & 13.40 & .18 & 3.82 & 7.02 & 2.65 & 2.11 & .88 & 99.23 \\
\hline 30 & 51.21 & 2.91 & 14.86 & 14.10 & .19 & 3.92 & 6.91 & 2.58 & 2.11 & .76 & 99.55 \\
\hline \multicolumn{12}{|c|}{$\begin{array}{l}\text { Kiperjärvenoja dyke } \\
\text { (metres) }\end{array}$} \\
\hline 0 & 47.12 & 3.22 & 18.02 & 13.32 & .19 & 4.76 & 7.44 & 2.96 & 1.44 & .69 & 99.16 \\
\hline 0.06 & 46.82 & 2.91 & 16.96 & 14.28 & .11 & 5.58 & 7.34 & 2.98 & 1.72 & .58 & 99.28 \\
\hline 0.12 & 46.98 & 2.97 & 17.52 & 13.97 & .16 & 5.56 & 6.99 & 2.85 & 1.36 & .77 & 99.13 \\
\hline 0.32 & 46.84 & 2.92 & 16.03 & 14.51 & .17 & 5.48 & 8.29 & 3.16 & 1.26 & .59 & 99.25 \\
\hline 0.75 & 48.52 & 3.23 & 16.21 & 13.57 & .18 & 4.61 & 8.87 & 2.92 & 1.26 & .45 & 99.82 \\
\hline 1.75 & 49.40 & 2.41 & 19.73 & 9.59 & .19 & 4.28 & 8.89 & 3.33 & 1.30 & .60 & 99.72 \\
\hline 3.90 & 46.74 & 2.95 & 16.02 & 14.39 & .18 & 4.96 & 9.45 & 3.13 & 1.21 & .65 & 99.68 \\
\hline 10 & 46.42 & 2.60 & 16.88 & 13.89 & .13 & 5.44 & 9.83 & 3.15 & 1.13 & .38 & 99.85 \\
\hline 23 & 48.51 & 2.94 & 16.84 & 13.04 & .15 & 4.87 & 8.23 & 3.16 & 1.55 & .44 & 99.73 \\
\hline 60 & 47.12 & 2.92 & 15.67 & 13.34 & .20 & 5.72 & 9.66 & 3.08 & 1.42 & .44 & 99.57 \\
\hline
\end{tabular}




\section{APPENDIX 2}

Groundmass composition of the Husö diabase dyke ( $\AA$ land diabase set).

\begin{tabular}{|c|c|c|c|c|c|c|c|c|c|c|c|c|}
\hline $\begin{array}{l}\text { Distance } \\
\text { from cont. } \\
(\mathrm{mm})\end{array}$ & $\begin{array}{l}\text { No. of } \\
\text { anal. }\end{array}$ & $\mathrm{SiO}_{2}$ & $\mathrm{TiO}_{2}$ & $\mathrm{Al}_{2} \mathrm{O}_{3}$ & $\mathrm{FeO}^{\mathrm{t}}$ & $\mathrm{MnO}$ & $\mathrm{MgO}$ & $\mathrm{CaO}$ & $\mathrm{Na}_{2} \mathrm{O}$ & $\mathrm{K}_{2} \mathrm{O}$ & $\mathrm{P}_{2} \mathrm{O}_{5}$ & Total \\
\hline 0 & 6 & 55.94 & 2.15 & 17.49 & 7.21 & .28 & 1.96 & 5.99 & 5.25 & 1.18 & .46 & 97.91 \\
\hline 1 & 3 & 46.35 & 2.07 & 13.43 & 18.46 & .37 & 6.87 & 4.87 & .99 & 3.68 & .46 & 97.55 \\
\hline 2 & 6 & 56.63 & 1.92 & 12.88 & 11.12 & .25 & 4.17 & 7.36 & 2.90 & 1.21 & .41 & 98.85 \\
\hline 4.5 & 5 & 53.43 & 1.97 & 13.25 & 12.68 & .23 & 5.06 & 8.10 & 2.75 & 1.12 & .43 & 99.02 \\
\hline 7.5 & 4 & 53.18 & 1.96 & 13.17 & 13.20 & .24 & 5.31 & 8.05 & 2.52 & 1.15 & .43 & 99.21 \\
\hline 11 & 3 & 52.42 & 2.00 & 13.40 & 13.66 & .19 & 5.21 & 8.09 & 2.46 & 1.05 & .43 & 98.91 \\
\hline 16 & 3 & 52.07 & 2.12 & 13.18 & 14.12 & .23 & 5.11 & 8.08 & 2.38 & .95 & .44 & 98.68 \\
\hline 20 & 4 & 52.65 & 1.91 & 13.42 & 14.50 & .21 & 4.97 & 7.79 & 2.38 & .90 & .43 & 99.16 \\
\hline 25 & 6 & 53.18 & 1.61 & 13.42 & 13.82 & .22 & 4.86 & 7.90 & 2.12 & .98 & .45 & 98.56 \\
\hline 30 & 4 & 53.59 & 1.71 & 13.35 & 12.95 & .22 & 4.85 & 8.21 & 2.05 & .93 & .44 & 98.29 \\
\hline 35 & 4 & 53.86 & 1.70 & 13.16 & 12.95 & .19 & 4.68 & 8.31 & 2.17 & 1.03 & .32 & 98.37 \\
\hline 40 & 3 & 53.36 & 1.77 & 13.24 & 13.19 & .22 & 4.71 & 8.00 & 2.35 & .85 & .38 & 98.07 \\
\hline 45 & 4 & 53.11 & 1.65 & 14.06 & 12.86 & .20 & 4.87 & 8.01 & 2.31 & .85 & .41 & 98.39 \\
\hline 50 & 4 & 52.57 & 1.71 & 14.24 & 13.38 & .17 & 4.94 & 8.07 & 2.28 & .88 & .44 & 98.68 \\
\hline 57 & 4 & 53.21 & 1.51 & 14.52 & 13.63 & .20 & 4.77 & 7.92 & 2.32 & .85 & .40 & 99.33 \\
\hline 62 & 4 & 52.15 & 1.84 & 14.24 & 13.71 & .21 & 4.72 & 7.91 & 2.49 & .74 & .42 & 98.43 \\
\hline 67 & 3 & 54.52 & 1.85 & 14.14 & 13.05 & .22 & 4.26 & 7.70 & 2.35 & .84 & .40 & 99.33 \\
\hline 73 & 4 & 53.92 & 1.95 & 14.15 & 13.24 & .27 & 4.42 & 7.72 & 2.37 & .84 & .41 & 99.34 \\
\hline 80 & 7 & 54.64 & 1.72 & 13.76 & 12.09 & .19 & 4.29 & 8.06 & 2.23 & .93 & .44 & 98.35 \\
\hline Centre & 7 & 54.09 & 1.79 & 14.06 & 11.64 & .21 & 4.47 & 8.32 & 2.31 & .96 & .42 & 98.27 \\
\hline 80 & 8 & 53.98 & 1.57 & 13.72 & 11.55 & .21 & 4.30 & 8.14 & 2.36 & .90 & .45 & 97.18 \\
\hline 75 & 7 & 56.23 & 1.55 & 14.14 & 10.77 & .19 & 4.04 & 8.15 & 2.41 & .96 & .44 & 98.88 \\
\hline 68 & 3 & 56.37 & 1.52 & 13.80 & 11.25 & .22 & 4.19 & 8.13 & 2.41 & .92 & .40 & 99.21 \\
\hline 62 & 4 & 55.86 & 1.47 & 14.21 & 11.18 & .18 & 4.33 & 8.00 & 2.34 & 1.01 & .41 & 98.99 \\
\hline 56 & 3 & 55.58 & 1.50 & 13.82 & 12.00 & .16 & 4.48 & 7.89 & 2.33 & .91 & .44 & 99.11 \\
\hline 52 & 7 & 54.70 & 1.49 & 14.28 & 12.12 & .19 & 4.70 & 8.15 & 2.31 & .86 & .42 & 99.22 \\
\hline 44 & 5 & 54.06 & 1.46 & 14.11 & 12.31 & .21 & 4.78 & 8.00 & 2.45 & .80 & .45 & 98.63 \\
\hline 40 & 4 & 53.57 & 1.49 & 14.18 & 13.28 & .18 & 5.17 & 8.18 & 2.43 & .81 & .47 & 99.76 \\
\hline 33 & 3 & 53.78 & 1.56 & 13.40 & 12.68 & .17 & 5.14 & 7.90 & 2.47 & 1.09 & .46 & 98.65 \\
\hline 27 & 4 & 53.26 & 1.58 & 13.56 & 12.66 & .18 & 5.11 & 8.07 & 2.36 & .89 & .45 & 98.78 \\
\hline 22 & 4 & 52.55 & 1.65 & 13.88 & 12.54 & .18 & 5.28 & 8.29 & 2.39 & .98 & .48 & 98.16 \\
\hline 13 & 6 & 53.79 & 1.63 & 14.04 & 12.41 & .19 & 5.12 & 8.19 & 2.48 & .81 & .46 & 99.12 \\
\hline 6 & 3 & 54.19 & 1.62 & 14.12 & 11.32 & .22 & 4.61 & 8.03 & 2.72 & .99 & .41 & 98.23 \\
\hline 1 & 6 & 53.62 & 1.73 & 17.09 & 9.24 & .26 & 2.80 & 7.07 & 5.94 & .81 & .40 & 98.91 \\
\hline 0 & 4 & 54.60 & 2.03 & 16.91 & 7.54 & .23 & 2.74 & 7.15 & 6.50 & .58 & .47 & 98.64 \\
\hline Average & 154 & 53.42 & 1.75 & 13.74 & 12.92 & .21 & 4.80 & 8.05 & 2.37 & .93 & .43 & 98.62 \\
\hline
\end{tabular}


APPENDIX 2 (continued)

Groundmass composition of the Vehkajärvi diabase dyke (Häme diabase set).

\begin{tabular}{|c|c|c|c|c|c|c|c|c|c|c|c|c|}
\hline $\begin{array}{l}\text { Distance } \\
\text { from cont. } \\
(\mathrm{cm})\end{array}$ & $\begin{array}{l}\text { No. of } \\
\text { anal. }\end{array}$ & $\mathrm{SiO}_{2}$ & $\mathrm{TiO}_{2}$ & $\mathrm{Al}_{2} \mathrm{O}_{3}$ & $\mathrm{FeO}^{\mathrm{t}}$ & $\mathrm{MnO}$ & $\mathrm{MgO}$ & $\mathrm{CaO}$ & $\mathrm{Na}_{2} \mathrm{O}$ & $\mathrm{K}_{2} \mathrm{O}$ & $\mathrm{P}_{2} \mathrm{O}_{5}$ & Total \\
\hline 0 & 5 & 49.47 & 3.08 & 14.18 & 13.35 & .26 & 3.82 & 7.40 & 4.43 & .92 & .87 & 97.78 \\
\hline 0.2 & 3 & 50.11 & 3.34 & 14.43 & 10.90 & .24 & 3.78 & 7.82 & 4.78 & .68 & .95 & 97.08 \\
\hline 0.6 & 4 & 49.92 & 2.88 & 14.49 & 12.53 & .22 & 3.74 & 7.26 & 3.66 & 1.76 & .76 & 97.22 \\
\hline 1.5 & 3 & 49.54 & 2.87 & 15.21 & 12.28 & .19 & 3.48 & 7.45 & 3.47 & 1.93 & .84 & 97.26 \\
\hline 1.8 & 3 & 50.34 & 2.65 & 15.17 & 12.81 & .21 & 3.24 & 6.89 & 3.35 & 2.14 & .84 & 97.64 \\
\hline 4 & 3 & 50.48 & 2.48 & 15.26 & 12.33 & .18 & 3.31 & 6.99 & 3.26 & 2.01 & .83 & 97.13 \\
\hline 8 & 4 & 50.83 & 2.61 & 15.33 & 12.71 & .19 & 3.18 & 7.12 & 3.41 & 2.26 & .79 & 98.43 \\
\hline 10 & $\begin{array}{l}7 \\
6\end{array}$ & 51.26 & 2.51 & 15.42 & 11.88 & .22 & 3.22 & 7.33 & 3.22 & 1.97 & .86 & 97.89 \\
\hline 15 & 6 & 52.33 & 2.33 & 15.58 & 11.63 & .18 & 3.16 & 7.21 & 3.40 & 2.06 & .85 & 98.73 \\
\hline 20 & 7 & 51.88 & 2.41 & 15.13 & 12.08 & .19 & 3.43 & 7.42 & 3.45 & 2.25 & .77 & 99.01 \\
\hline 25 & 3 & 52.22 & 2.31 & 15.21 & 12.01 & .21 & 3.33 & 7.13 & 3.31 & 1.88 & .79 & 98.40 \\
\hline 35 & 8 & 51.78 & 2.22 & 15.61 & 11.97 & .18 & 3.35 & 7.28 & 3.16 & 2.00 & .85 & 98.40 \\
\hline 50 & 5 & 52.28 & 2.52 & 15.37 & 11.77 & .18 & 3.13 & 7.39 & 3.47 & 1.90 & .83 & 98.84 \\
\hline 82 & 3 & 52.36 & 2.42 & 15.62 & 12.03 & .19 & 3.36 & 7.18 & 3.37 & 1.80 & .81 & 99.14 \\
\hline 110 & 5 & 52.42 & 2.53 & 15.78 & 12.12 & .19 & 3.41 & 7.32 & 3.41 & 1.92 & .82 & 99.92 \\
\hline 125 & 6 & 49.49 & 2.99 & 14.81 & 15.13 & .16 & 4.07 & 6.98 & 2.72 & 1.96 & .79 & 99.10 \\
\hline 142 & 8 & 50.25 & 3.84 & 14.34 & 14.91 & .17 & 4.14 & 6.77 & 2.41 & 2.17 & .74 & 99.74 \\
\hline \multicolumn{13}{|l|}{ Centre } \\
\hline 148 & 9 & 50.12 & 3.92 & 14.21 & 15.08 & .18 & 4.21 & 6.61 & 2.38 & 2.21 & .72 & 99.64 \\
\hline 110 & 5 & 52.30 & 2.42 & 15.61 & 12.28 & .20 & 3.39 & 7.21 & 3.38 & 1.99 & .88 & 99.66 \\
\hline 42 & 5 & 51.31 & 2.38 & 15.48 & 12.01 & .19 & 3.48 & 7.19 & 3.36 & 2.08 & .93 & 98.41 \\
\hline 30 & 3 & 52.23 & 2.48 & 15.12 & 11.81 & .17 & 3.12 & 7.22 & 3.21 & 1.99 & .86 & 98.21 \\
\hline 28 & 3 & 51.62 & 2.41 & 15.13 & 11.97 & .17 & 3.26 & 7.18 & 3.31 & 2.06 & .87 & 97.98 \\
\hline 6 & 4 & 50.82 & 2.59 & 15.11 & 12.38 & .19 & 3.52 & 7.26 & 3.46 & 1.89 & .79 & 98.01 \\
\hline 2.5 & 3 & 50.22 & 2.78 & 14.98 & 12.29 & .18 & 3.62 & 7.46 & 3.72 & 1.72 & .81 & 97.78 \\
\hline 2 & 3 & 49.36 & 2.63 & 14.89 & 12.37 & .22 & 3.56 & 7.33 & 3.98 & 1.01 & .82 & 96.97 \\
\hline 0.8 & 4 & 48.72 & 2.92 & 15.01 & 12.08 & .19 & 3.48 & 7.61 & 4.31 & .81 & .76 & 96.89 \\
\hline 0.3 & 4 & 49.81 & 3.08 & 14.92 & 10.70 & .29 & 3.76 & 7.90 & 4.72 & .66 & .90 & 96.74 \\
\hline 0.1 & 6 & 50.12 & 3.31 & 14.48 & 11.02 & .28 & 3.61 & 7.71 & 4.60 & 1.02 & .92 & 97.08 \\
\hline 0 & 7 & 48.81 & 3.28 & 14.36 & 13.92 & .31 & 3.92 & 7.52 & 4.52 & .92 & .77 & 98.23 \\
\hline Average & 109 & 51.32 & 2.56 & 15.42 & 11.85 & .18 & 3.27 & 7.30 & 3.36 & 1.99 & .84 & 98.09 \\
\hline
\end{tabular}

Groundmass composition of the Kiperjärvenoja dyke (Satakunta diabase set)

$\begin{array}{lrrrrrrrrrrrr}0 & 2 & 47.40 & 3.41 & 12.31 & 18.72 & .17 & 6.55 & 2.10 & 1.41 & 2.38 & .54 & 94.99 \\ 0.5 & 3 & 44.79 & 4.14 & 12.43 & 16.00 & .18 & 8.33 & 3.09 & 1.56 & 3.27 & .43 & 94.22 \\ 1 & 2 & 45.86 & 2.81 & 16.77 & 11.33 & .09 & 4.86 & 6.48 & 2.92 & 2.86 & .49 & 94.48 \\ 2 & 2 & 46.20 & 3.19 & 17.72 & 11.36 & .10 & 5.16 & 6.10 & 3.08 & 2.78 & .59 & 96.18 \\ 4 & 3 & 47.89 & 1.77 & 17.64 & 10.43 & .09 & 5.14 & 6.60 & 3.39 & 1.24 & .48 & 94.67 \\ 6 & 8 & 47.86 & 2.56 & 17.49 & 12.42 & .09 & 5.08 & 6.90 & 3.42 & 1.96 & .46 & 98.27 \\ 10 & 5 & 47.77 & 2.41 & 17.26 & 11.86 & .17 & 4.89 & 7.21 & 3.47 & 1.14 & 2.10 & 98.17 \\ \text { Average } & 15 & 47.89 & 2.59 & 17.49 & 11.36 & .10 & 4.90 & 7.10 & 3.42 & 1.24 & .55 & 96.64\end{array}$


APPENDIX 3

Some representative microprobe analyses of plagioclase.

\begin{tabular}{|c|c|c|c|c|c|c|c|c|c|}
\hline & & $\mathrm{SiO}_{2}$ & $\mathrm{Al}_{2} \mathrm{O}_{3}$ & $\mathrm{FeO}^{\mathrm{t}}$ & $\mathrm{CaO}$ & $\mathrm{Na}_{2} \mathrm{O}$ & $\mathrm{K}_{2} \mathrm{O}$ & Total & An \\
\hline \multicolumn{10}{|c|}{ Aland diabase set } \\
\hline \multirow[t]{7}{*}{ Bergskär } & $\mathrm{pc}_{\mathrm{e}}$ & 54.95 & 28.26 & .75 & 10.72 & 5.29 & .34 & 100.28 & 52.8 \\
\hline & $\mathrm{pc}_{\mathrm{r}}$ & 54.05 & 28.79 & .76 & 11.21 & 5.15 & .26 & 100.22 & 54.6 \\
\hline & $\mathrm{pc}_{\mathrm{c}}$ & 54.91 & 27.88 & .53 & 10.35 & 5.27 & .36 & 99.30 & 52.0 \\
\hline & $\mathrm{pc}_{\mathrm{r}}$ & 54.92 & 28.20 & .81 & 10.78 & 5.09 & .24 & 100.04 & 53.9 \\
\hline & $\mathrm{gm}$ & 53.12 & 29.11 & 1.25 & 12.24 & 4.50 & .38 & 100.60 & 60.1 \\
\hline & $\mathrm{gm}$ & 53.87 & 28.49 & 1.26 & 11.49 & 4.81 & .26 & 100.18 & 56.9 \\
\hline & $\mathrm{gm}$ & 54.39 & 28.28 & .86 & 10.70 & 5.25 & .24 & 99.72 & 52.9 \\
\hline \multirow[t]{7}{*}{ Betesö } & $\mathrm{pc}_{\mathrm{c}}$ & 55.38 & 29.11 & .16 & 8.42 & 6.04 & .57 & 99.68 & 43.5 \\
\hline & $\mathrm{pc}_{\mathrm{r}}$ & 54.89 & 29.11 & .19 & 7.69 & 6.20 & 1.86 & 99.94 & 40.7 \\
\hline & $\mathrm{pc}_{\mathrm{c}}$ & 58.38 & 25.75 & .29 & 7.50 & 8.27 & .10 & 100.29 & 33.4 \\
\hline & $\mathrm{pc}_{\mathrm{r}}$ & 60.03 & 24.73 & .18 & 5.38 & 9.33 & .15 & 99.80 & 24.2 \\
\hline & $\mathrm{gm}$ & 57.26 & 25.92 & .20 & 9.36 & 7.10 & .06 & 99.90 & 42.1 \\
\hline & $\mathrm{gm}$ & 55.37 & 27.81 & .37 & 10.33 & 6.54 & .01 & 100.34 & 46.6 \\
\hline & $\mathrm{gm}$ & 59.04 & 25.69 & .13 & 7.23 & 8.05 & .01 & 100.15 & 33.2 \\
\hline \multirow[t]{7}{*}{ Källsholm } & $\mathrm{pc}_{\mathrm{e}}$ & 54.52 & 27.64 & .59 & 10.68 & 5.83 & .66 & 99.92 & 50.3 \\
\hline & $\mathrm{pc}_{\mathrm{r}}$ & 54.68 & 27.61 & .60 & 11.53 & 5.37 & .44 & 100.23 & 54.3 \\
\hline & $\mathrm{pc}_{\mathrm{c}}$ & 55.36 & 27.09 & .42 & 11.05 & 6.25 & .48 & 100.65 & 49.4 \\
\hline & $\mathrm{pc}_{\mathrm{r}}$ & 56.11 & 25.86 & .32 & 10.12 & 6.82 & .46 & 99.69 & 45.1 \\
\hline & $\mathrm{gm}$ & 53.54 & 28.45 & .66 & 11.60 & 5.03 & .34 & 99.62 & 56.0 \\
\hline & $\mathrm{gm}$ & 48.88 & 27.56 & 1.33 & 18.71 & 3.27 & .16 & 99.91 & 76.0 \\
\hline & $\mathrm{gm}$ & 55.15 & 27.39 & .55 & 10.46 & 6.06 & .63 & 100.24 & 48.8 \\
\hline \multicolumn{10}{|c|}{ Häme diabase set } \\
\hline \multirow[t]{7}{*}{ Orivesi I } & $\mathrm{pc}_{\mathrm{c}}$ & 52.17 & 30.42 & .50 & 12.77 & 3.84 & .31 & 100.01 & 64.8 \\
\hline & $\mathrm{pc}_{\mathrm{r}}$ & 56.16 & 27.19 & .68 & 9.72 & 5.21 & 1.06 & 99.92 & 50.7 \\
\hline & $\mathrm{pc}_{\mathrm{e}}$ & 53.95 & 29.31 & .55 & 11.53 & 4.57 & .50 & 100.41 & 58.2 \\
\hline & $\mathrm{pc}_{\mathrm{r}}$ & 55.89 & 28.02 & .63 & 9.93 & 5.20 & .82 & 100.49 & 51.3 \\
\hline & $\mathrm{gm}$ & 54.47 & 28.26 & .83 & 10.97 & 4.84 & .74 & 100.11 & 55.6 \\
\hline & $\mathrm{gm}$ & 54.43 & 28.42 & .67 & 10.70 & 4.88 & .59 & 99.69 & 54.8 \\
\hline & $\mathrm{gm}$ & 54.86 & 28.37 & .73 & 10.52 & 5.02 & .43 & 99.93 & 53.5 \\
\hline \multirow[t]{7}{*}{ Orivesi II } & $\mathrm{pc}_{\mathrm{c}}$ & 53.06 & 28.26 & .66 & 11.61 & 5.30 & .76 & 99.65 & 54.6 \\
\hline & $\mathrm{pc}_{\mathrm{r}}$ & 55.50 & 27.60 & .88 & 10.29 & 4.80 & .82 & 99.89 & 54.1 \\
\hline & $\mathrm{pc}_{\mathrm{c}}$ & 52.40 & 28.65 & .61 & 11.84 & 4.70 & .92 & 99.12 & 58.1 \\
\hline & $\mathrm{pc}_{\mathrm{r}}$ & 55.19 & 28.00 & .82 & 9.83 & 5.03 & 1.02 & 99.89 & 51.9 \\
\hline & $\mathrm{gm}$ & 53.24 & 28.10 & .73 & 11.36 & 5.32 & .92 & 99.67 & 54.1 \\
\hline & $\mathrm{gm}$ & 54.44 & 27.65 & .79 & 10.65 & 5.51 & .73 & 99.77 & 51.7 \\
\hline & $\mathrm{gm}$ & 55.19 & 28.00 & .63 & 9.83 & 4.83 & 1.02 & 99.50 & 52.9 \\
\hline \multirow[t]{7}{*}{ Orivesi III } & $\mathrm{pc}_{\mathrm{c}}$ & 54.02 & 29.71 & .30 & 11.82 & 4.03 & .40 & 100.28 & 61.7 \\
\hline & $\mathrm{pc}_{\mathrm{r}}$ & 55.13 & 27.92 & .48 & 9.74 & 5.02 & 1.03 & 99.32 & 51.7 \\
\hline & $\mathrm{pc}_{\mathrm{c}}$ & 53.27 & 30.08 & .27 & 12.31 & 3.96 & .36 & 100.25 & 63.2 \\
\hline & $\mathrm{pc}_{\mathrm{r}}$ & 55.59 & 27.91 & .64 & 9.92 & 5.12 & 1.02 & 100.20 & 51.7 \\
\hline & $\mathrm{gm}$ & 53.04 & 29.88 & .63 & 12.19 & 4.28 & .47 & 100.49 & 59.5 \\
\hline & $\mathrm{gm}$ & 53.92 & 28.92 & .66 & 11.31 & 4.52 & .62 & 99.94 & 57.9 \\
\hline & $\mathrm{gm}$ & 54.38 & 28.66 & .62 & 10.61 & 4.92 & .72 & 99.91 & 54.4 \\
\hline \multicolumn{10}{|c|}{ Satakunta diabase set } \\
\hline Hinnerjoki & $\mathrm{mc}$ & 66.92 & 20.17 & .02 & .06 & .10 & 11.65 & 98.92 & - \\
\hline \multirow[t]{3}{*}{ I and II } & $\mathrm{mc}$ & 67.47 & 19.72 & .15 & .00 & .10 & 12.43 & 99.87 & - \\
\hline & $\mathrm{pc}$ & 50.92 & 30.57 & .62 & 13.35 & 3.65 & .19 & 99.30 & 66.9 \\
\hline & $\mathrm{gm}$ & 50.65 & 30.17 & .69 & 12.87 & 4.00 & .21 & 98.59 & 64.0 \\
\hline
\end{tabular}

mc - megacryst

$\mathrm{pc}_{\mathrm{c}}$ - phenocryst core

$\mathrm{pc}_{\mathrm{r}}$ - phenocryst rim

gm - groundmass plagioclase 